\title{
Fault-Related Controls on Upward Hydrothermal Flow: An Integrated Geological Study of the Têt Fault System, Eastern Pyrénées (France)
}

\author{
Audrey Taillefer, ${ }^{1}$ Roger Soliva, ${ }^{1}$ Laurent Guillou-Frottier, ${ }^{2}$ Elisabeth Le Goff, ${ }^{3}$ \\ Guillaume Martin, ${ }^{4}$ and Michel Seranne ${ }^{1}$ \\ ${ }^{1}$ Géosciences Montpellier, UMR 5243, Université de Montpellier, CNRS, Place Eugène Bataillon, 34095 Montpellier Cedex 5, France \\ ${ }^{2}$ BRGM, ISTO, UMR 7327, 3 av. C. Guillemin, BP 36009, 45060 Orléans Cedex 2, France \\ ${ }^{3}$ BRGM Occitanie-Site de Montpellier (Direction Régionale), 1039 rue de Pinville, 34000 Montpellier, France \\ ${ }^{4}$ Calle Austria 2181, Asuncion, Paraguay
}

Correspondence should be addressed to Audrey Taillefer; audrey.taillefer@gm.univ-montp2.fr

Received 25 November 2016; Revised 8 March 2017; Accepted 23 April 2017; Published 2 August 2017

Academic Editor: Mark Tingay

Copyright (C) 2017 Audrey Taillefer et al. This is an open access article distributed under the Creative Commons Attribution License, which permits unrestricted use, distribution, and reproduction in any medium, provided the original work is properly cited.

\begin{abstract}
The way faults control upward fluid flow in nonmagmatic hydrothermal systems in extensional context is still unclear. In the Eastern Pyrénées, an alignment of twenty-nine hot springs $\left(29^{\circ} \mathrm{C}\right.$ to $\left.73^{\circ} \mathrm{C}\right)$, along the normal Têt fault, offers the opportunity to study this process. Using an integrated multiscale geological approach including mapping, remote sensing, and macro- and microscopic analyses of fault zones, we show that emergence is always located in crystalline rocks at gneiss-metasediments contacts, mostly in the Têt fault footwall. The hot springs distribution is related to high topographic reliefs, which are associated with fault throw and segmentation. In more detail, emergence localizes either (1) in brittle fault damage zones at the intersection between the Têt fault and subsidiary faults or (2) in ductile faults where dissolution cavities are observed along foliations, allowing juxtaposition of metasediments. Using these observations and 2D simple numerical simulation, we propose a hydrogeological model of upward hydrothermal flow. Meteoric fluids, infiltrated at high elevation in the fault footwall relief, get warmer at depth because of the geothermal gradient. Topography-related hydraulic gradient and buoyancy forces cause hot fluid rise along permeability anisotropies associated with lithological juxtapositions, fracture, and fault zone compositions.
\end{abstract}

\section{Introduction}

Studying hydrothermal fluid flow through fault zones is important to understand thermal perturbations of the Earth's crust and can provide strong constraints on deep geothermal exploration. The fault-related geothermal systems which are currently studied $[1,2]$ focus on magmatic types (e.g., Bouillante [3]), rifts (e.g., East African Rift $[4,5]$ ), or continental grabens (e.g., Soultz-sous-Forêts [6]). Nonmagmatic hydrothermal systems in continental contexts involving high relief and hot springs [7] are rarely studied [8]. Further, processes acting in this kind of hydrothermal systems are essentially explored by numerical models $[9,10]$ (e.g., the Dixie Valley geothermal field in Nevada [11-13]), and integrative geological studies as proposed in this paper are few in number [7, 14-16].

Faults have been involved in controlling water upflow, as proved by the emergence of hot springs adjacent to normal fault scarps, and associated reliefs [17]. Based on numerical studies, conceptual models suggest that meteoric water infiltrates from the top of the ranges to kilometric depths, before rising up to the surface through permeable zones. Topography [18-20], buoyancy forces [21, 22], and groundwater recharge [19], inducing both a hydraulic gradient and thermal disturbance, exert a significant role on hydrothermal circulation. Petrophysical and thermal properties, especially permeability [23], play a critical role in the establishment of a fluid circulation pattern and thus in the building of possible 
thermal anomalies [11, 24]. Without magmatic activity, the mantle-derived crustal heat is responsible for the meteoric fluid warming. During their transfer in the crust, hot fluids alter rocks and become mineralized. Because of the decompression and cooler conditions in surface, mineralized fluids precipitate as alteration deposits (including quartz and carbonates sinter or travertine [25]) which may be used as evidence of hydrothermal circulations [26].

Faults are often mentioned as important structures providing strong permeability anisotropy in the Earth crust [15, 27]. The variability of brittle fault zones permeability has been widely discussed these last twenty years [27]. Depending on the stratigraphic column and displacements scale [28], faults juxtapose compartments which may be sealant or highly permeable [29]. Fault zones may involve one or several core zones, composed of fault rocks, surrounded by a damage zone corresponding to highly fractured host rocks. The core zone permeability largely depends on the grain size and matrix content of fault rocks. If they are cataclastic, a higher proportion of fine matrix coincides with lower permeability in the fault rocks $[30,31]$. Presence of clay incorporated by smearing or resulting from pressure solution zones as insoluble minerals also drastically reduces permeability [32, 33 . In general, two damage zones composed of highly fractured host rocks surround the core zone [34]. Damage zones have a strong influence on fault permeability, depending on fractures aperture, density, connectivity, and cementation [35-38]. These properties may vary along fault according to the fault architecture, that is, intersections of fractured damage zones [39-41] or fault segmentation [37, 42, 43]. The fault constitution and the fracture network also evolve with time, as potential mineralized fluids may corrode or seal permeable structures, respectively, enhancing or reducing the permeability. Fluid-rock interaction may interplay with the seismic cycle, where pore pressure and stress orientation are also known to be essential factors influencing fractures or breccia pores opening; as such, they maintain fluid flow [28, 44-48].

An interplay of these geometrical/petrophysical factors leads to an upward hydrothermal flow within fault zones $[1,14,40]$. However, there is no clear evidence of which of these factors, if any, exerts a primary influence. In addition, these fault-related parameters can interact with constraints inherent to the bulk hydrothermal system (topography and the resulting hydraulic gradient, temperature contrasts, and resulting buoyancy forces), making the understanding of their relationship quite complex. For all these reasons, it is worth analyzing all the parameters cited above (fault zone, lithology, topography, and spring features) into an integrative approach to provide better constraints for numerical models.

In the French Pyrénées, at least 100 hot springs emerge along the $500 \mathrm{~km}$ long range (Figure 1). The location of most of them is clearly related to the presence of major faults. In this study, we focus on the case of the crustal-scale $100 \mathrm{~km}$ long Têt fault, in the eastern part of the range. Twenty-nine hot springs with high temperatures align along this Neogene brittle fault postdating Pyrenean shortening. The Têt fault juxtaposes different lithological units including Neoproterozoic to Paleozoic metasediments, gneiss formed during the
Hercynian orogen, post-Hercynian granite, and Neogene syntectonic sediments. The fault scarp, culminating at around $3000 \mathrm{~m}$, forms a high topographic gradient able to induce isotherm disturbance without the presence of an abnormal heat source. Moderate microseismicity [49] may maintain open hydrothermal conduits. Consequently, the Têt fault hydrothermal system is ideal for an integrated study of fault controls on upward hot fluid flow. Previous studies of the Têt hot springs are essentially based on analytical solutions [10], or geochemistry [50], but none of them was able to provide a geologically consistent hydrodynamic model. This study is a multiscale approach based on mapping, topography analysis, field observation, microscopy, and preliminary numerical models, allowing identifying and prioritizing which factors control hot springs in this hydrothermal system.

\section{Geological Setting}

The Pyrenean range (Figure 1) is a doubly vergent orogen formed during the Eocene period and resulting from the collision between the European and Iberic plates. The axial zone of the Pyrénées provides outcrops of Hercynian basement and faults, such as the CMNC "Chevauchement Mylonitic Nord Canigou" (Mylonitic North Canigou Thrust). This ductile Hercynian shear zone juxtaposes the Paleozoic gneiss of the Canigou-Carança dome and Paleozoic metamorphic sedimentary series (metasediments with intercalated carbonate beds) [52]. These basement rocks are intruded by the late Hercynian "Mont-Louis" granite in the NW part of the area. Pyrenean tectonic events are not well expressed in the study area, except with some thrusts (Merens) and pervasive mode $1 \mathrm{~N}-\mathrm{S}$ fracturing [53]. Pyrenean metamorphism is inexistent compared with the high temperature metamorphism associated with the Cretaceous extensional prealpine deformation [54].

The $100 \mathrm{~km}$ long brittle Têt fault is a normal fault formed during the Oligo-Miocene NW-SE extension responsible for the Gulf of Lion opening [55]. It first played as a dextral strike-slip fault and then as a normal fault, with a propagation of the deformation from the East to the West. Maximum exhumation occurs at 26-27 Ma [56] for the eastern part of the fault, with an estimated $2000 \mathrm{~m}$ offset allowing the formation of the Canigou-Carança mountain ranges. The activity decreases during the Miocene, despite reactivation as a normal fault during the Messinian period [56]. During the Pliocene, a transtensional extension [57] followed a compressional phase [58] expressed by sinistral strike-slip faulting. The Quaternary activity of the fault is still debated. Briais et al. [59] and Calvet [60] attribute the triangular facets of the Têt fault scarp to its recent normal activity, while Petit and Mouthereau [61] suggest they are actually the morphological expression of the CMNC corroborating with the differential erosion of the hosting rocks. Authors agree that current displacements are low or nonexistent [56, 57, 60, 62-64]. The general tectonic regime seems to have changed during the Pliocene from normal $[58,64,65]$ to reverse, but with no clear evidence about the compressive or strike-slip nature of the stress tensor [58]. Authors also agree to differentiate the Têt fault activity with two principal Têt fault segments: 


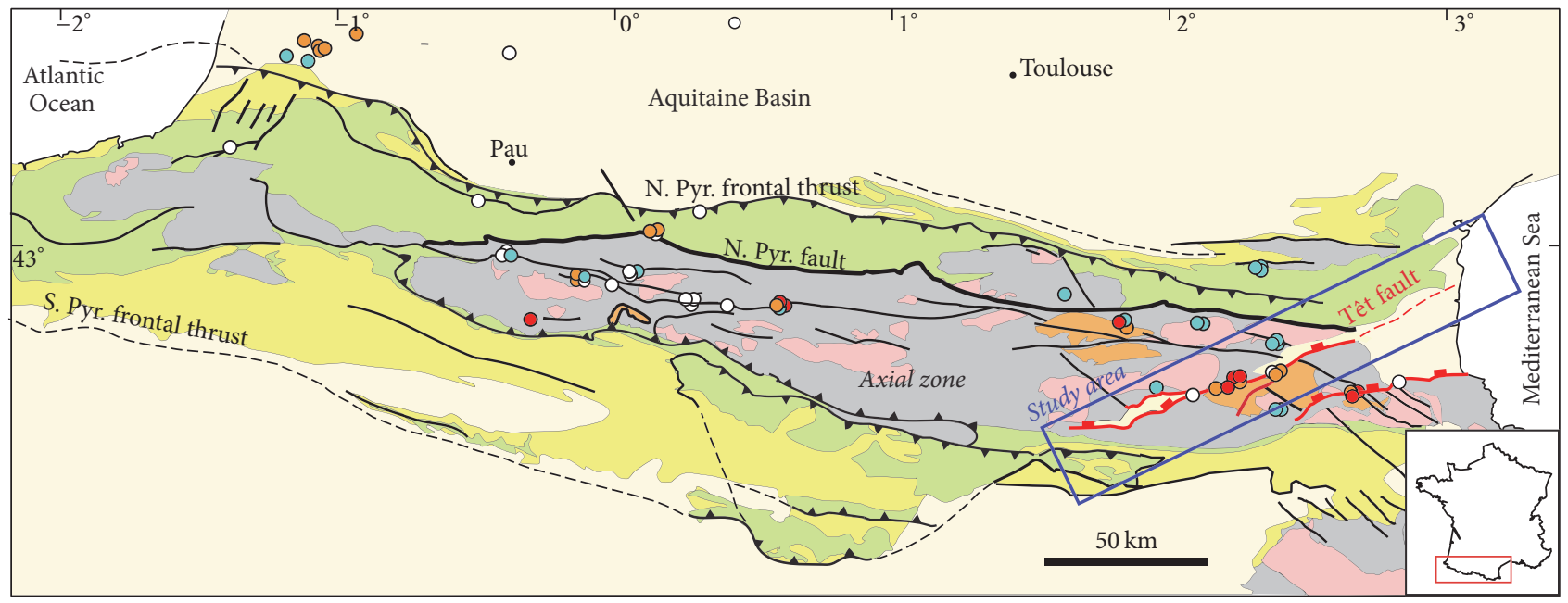
Tertiary in forelands
Pyrenean tertiary

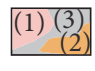
Paleozoic basement
(1) Granite
(2) Gneiss
(3) Paleoproterozoic
sediments

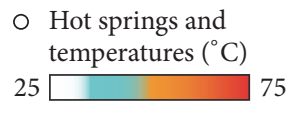

FIgURE 1: Structural sketch of the Pyrenean Range. South of France (modified from [51]). Hot springs are common along major faults, but the highest temperatures and the largest number of hot springs is found along the normal Têt fault. The study area, in blue, is outlined.

the western Cerdagne segment and the eastern Conflent segment. There is Pliocene evidence of reverse movements in Cerdagne and Conflent, but exclusively of sinistral strikeslip in Conflent $[58,60,65]$. In addition, reverse faulting affects Quaternary sediments of the Cerdagne basin [58, 66], while normal faulting affects post-Pliocene terraces near the Conflent segment [65]. Present-day moderate seismicity (i.e., magnitudes ranging from 2 to 4 ) is observed in the area [58] with an alignment of hypocenters along the Têt fault [49]. The stress tensor is either strike-slip or compressive, with a maximum horizontal compression between NE-SW [58] and N-S [66]. At the Pyrenean range scale, the role of erosion as the control of the flexural rebound would be responsible for the normal seismicity in the center of the Pyrenean Range [67] and potentially for thrusting in the foreland [68].

\section{Hydrological Setting}

Ph.D. thesis of Krimissa [50] and BRGM (French Geological Survey) reports [69-72] indicate that the temperatures of the hot springs vary between $29^{\circ} \mathrm{C}$ and $73^{\circ} \mathrm{C}$. In addition, stable isotopes ${ }^{18} \mathrm{O}$ and ${ }^{2} \mathrm{H}$ show that hydrothermal fluids have a meteoric origin and infiltrate in climatic conditions that are likely similar to the current ones. Recharge areas would be in high elevations zones, above $2000 \mathrm{~m}$. The poor reactivity of the water, as well as the same ${ }^{87} \mathrm{Sr} /{ }^{86} \mathrm{Sr}$ ratio for all the hot springs, would indicate that they migrate in a common reservoir, consisting only of crystalline rocks (gneiss and granite). Residence times calculated from the ${ }^{14} \mathrm{C}$ activity in the rocks range between 5000 and 13,000 years. Based on simplified 1D models in Velard [10], minimum surface of infiltration is estimated to be of $300 \mathrm{~km}^{2}$, and the length between infiltration areas and hot springs ranges from 10 to $20 \mathrm{~km}$ [73]. However, these simplified models consider the Têt fault role as a unique $3000 \mathrm{~m}$ long fracture and thus do not account for the complexity of the whole hydrothermal system.

Further, siliceous, Na-K, and $\mathrm{Na}-\mathrm{Li}$ geothermometers [50] indicate that water reaches temperature of more than $100^{\circ} \mathrm{C}$. However, these values have to be used carefully, because such methods are not always appropriate for siliceous rocks [74]. Consequently, the simplified hydrologic model of Velard [10] (see above), which is supported by similar data, would not be valid.

\section{Methods}

4.1. Combined Mapping Method. We combined geologic maps [52, 75], interpretation of SPOT (Système Pour l'Observation de la Terre: French remote sensing satellite) images ( $5 \mathrm{~m}$ resolution), aerial pictures ( $5 \mathrm{~m}$ resolution), and digital elevation model (USGS, $30 \mathrm{~m}$ resolution) with the QGIS 2.12 software for precise interpretation of the structures in the study area.

The main Neogene brittle faults are highlighted by characteristic geomorphological objects (reliefs, triangular facets, and basins) [76]. Mapping of these faults has been mainly derived from topography ruptures observed in DEM (see Section 5.1) allowing the author to make the distinction between brittle-Neogene normal faults from ductile Hercynian reverse faults (shear zones) and from brittle to ductilePyrenean reverse faults. Smaller faults patterns are identified using lineament mapping on satellite and aerial images and confirmed or completed by fieldwork. 


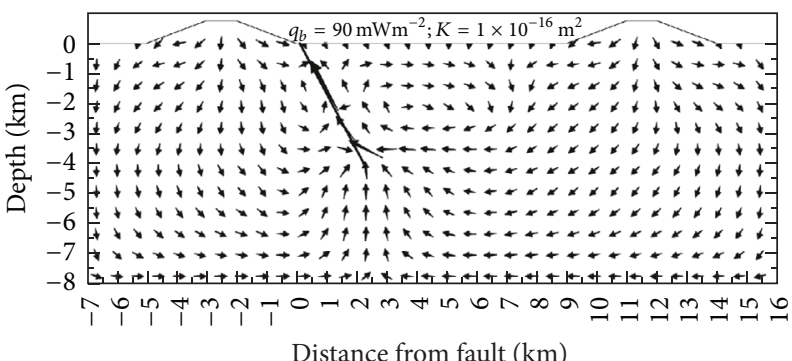

(a)

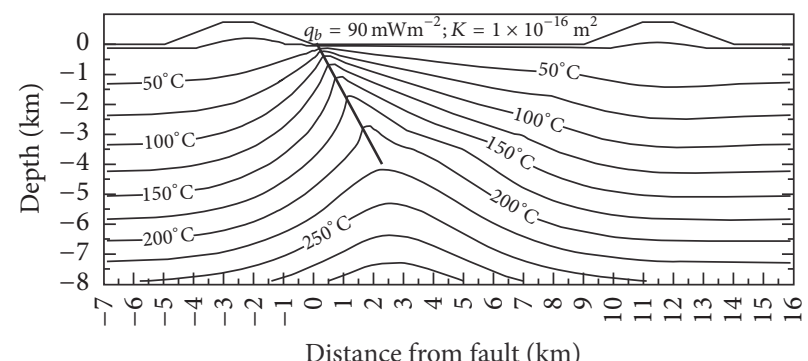

(b)

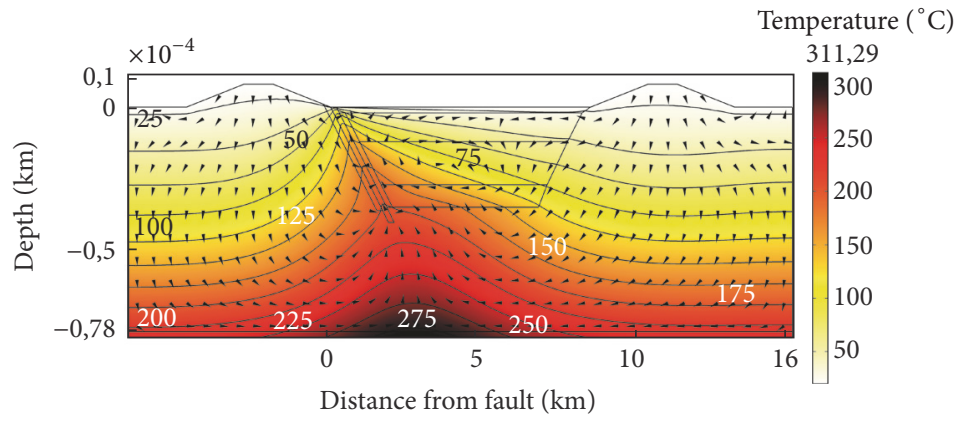

(c)

Figure 2: Benchmark of Dixie Valley, from McKenna and Blackwell models (2004) [11], using Comsol Multiphysics ${ }^{\mathrm{TM}}$ software numerical models coupling a Darcy law with the law of heat transfer equation in a porous media. (a) Steady state flow regime in Dixie Valley model obtained by McKenna and Blackwell (2004) in Figure 6. (b) Thermal flow regime of the same model. (c) Benchmark showing the same isotherm pattern and temperature distribution.

Most of the springs, including their temperatures, were collected from the BRGM database, Annales des Mines database, and the Ph.D. thesis of Krimissa [50]. Unfortunately, these studies are unclear on certain names or locations from the whole springs catalogue (rare maps and no GPS waypoints). Fieldwork precisely locates and references the essential features of springs (altitude, temperature, $\mathrm{pH}$ level, and electric conductivity). The numerical values are presented in Table 1.

4.2. Numerical Modeling. A 2D numerical model of the study area has been performed in order to integrate our observations with the petrophysical properties of the crust. Using the Comsol Multiphysics ${ }^{\mathrm{TM}}$ software, the heat transfer equation and Darcy's law have been coupled through a similar procedure as that used by Guillou-Frottier et al. [77].

We first reproduce one of the McKenna and Blackwell's numerical results [11] as a benchmark experiment (Figure 2). Indeed, the Têt Valley presents similar features to the Dixie Valley hydrothermal system. However, the Têt Valley reliefs are higher, basins are smaller or even inexistent, and geometry is asymmetrical. Figures 2(a) and 2(b) show the temperature and velocity fields, respectively, obtained in McKenna and Blackwell's models, for a fault permeability of $10^{-14} \mathrm{~m}^{2}$ and a host rock permeability of $10^{-16} \mathrm{~m}^{2}$. Figure $2(\mathrm{c})$ corresponds to our benchmark experiment, reproducing similar results with identical physical properties and identical boundary conditions (shape of uplifted isotherms and general fluid flow pattern). However, we note that the obtained velocity values within the fault are around $10^{-8} \mathrm{~m} / \mathrm{s}$, as in other similar studies $[41,78]$, whereas McKenna and Blackwell indicate a maximum velocity value of $3.7 \times 10^{-10} \mathrm{~m} / \mathrm{s}$, generally too low to disturb significantly a thermal field (see the detailed numerical models by López and Smith [78], where significant distortion of the thermal field is obtained for velocity around $10^{-7} \mathrm{~m} / \mathrm{s}$ ). In our numerical scheme being identical as in other studies $[79,80]$ where other benchmark tests were performed $[81,82]$, we validate our benchmark test of the Dixie Valley hydrothermal system.

\section{Results: Map Scale Analysis}

5.1. Faults, Lithologies, and Spring Emergence. We first compile hot spring features with mapping of faults and lithology on a digital elevation model (DEM) to identify which map scale structural parameters control the localization of the springs (Figure 3).

The brittle normal Têt fault is the main structure in the area. Its average strike is $\mathrm{N} 060 \mathrm{E}$, dipping $60^{\circ}$ to the North. The Têt fault is separated into four main segments (Cerdagne, Carança, Conflent, and Py), linked together at three main relays. The Cerdagne and Conflent segments limit two important basins (of the same name) infilled with Neogene sediments. The Carança and Py faults juxtapose Paleozoic rocks. Numerous subsidiaries E-W to NW-SE trending brittle faults collapse compartments on both sides of the Têt fault.

The Têt fault segmentation and the subsidiaries brittle faults delimit three principal ranges: the Puigmal Range (associated with the Cerdagne segment), the Carança Range 
TABLE 1: The Têt Valley hot springs location and features.

\begin{tabular}{|c|c|c|c|c|c|c|c|c|}
\hline Locality & Spring name & Data sources & Lat & Lon & Alt (m) & Temp $\left({ }^{\circ} \mathrm{C}\right)$ & $\mathrm{pH}$ & Cond $(\mu \mathrm{S} / \mathrm{cm})$ \\
\hline Llo & Llo & This study & 42.451130 & 2.061080 & 1390 & 29.1 & 9.4 & 342 \\
\hline \multirow{5}{*}{ Saint-Thomas-les-bains } & Grande Source & This study & 42.500240 & 2.167460 & 1156 & 55.3 & 9.15 & 306 \\
\hline & Baraquette 1 & This study & 42.50079 & 2.16746 & 1156 & 46.8 & 9.32 & 303 \\
\hline & Baraquette 2 & This study & 42.50079 & 2.16746 & 1156 & 45.3 & & 303 \\
\hline & Baraquette 3 & Unpublished data & 42.499767 & 2.167301 & 1156 & 48.5 & & \\
\hline & Douches & Unpublished data & 42.499943 & 2.167420 & 1156 & 57 & & \\
\hline \multirow{3}{*}{ Prats-Balaguer } & Aigues 1-1 & This study & 42.504250 & 2.182470 & 1190 & 60 & 9.16 & 317 \\
\hline & Aigues 1-2 & This study & 42.504250 & 2.182470 & 1190 & 60.7 & 9.15 & 315 \\
\hline & Aigues 2 & This study & 42.5044 & 2.181761 & 1160 & 38.7 & 9.37 & 301 \\
\hline \multirow{10}{*}{ Thues-les-bains } & Midi & This study & 42.528590 & 2.247560 & 747 & 39.1 & 9.14 & 309 \\
\hline & Saint-Louis & This study & 42.528581 & 2.248090 & 760 & 35 & 8.37 & 289 \\
\hline & Portail & This study & 42.528480 & 2.247250 & 747 & 63.9 & 8.93 & 323 \\
\hline & Escalade 1 & This study & 42.528130 & 2.249140 & 810 & 58.4 & 9.01 & 316 \\
\hline & Beauté & Krimissa 1992 & 42.528130 & 2.247145 & 770 & 66 & 9.1 & 624 \\
\hline & Gr. Saint-André & Krimissa 1992 & 42.528226 & 2.247747 & 770 & 73.2 & 9.6 & 563 \\
\hline & Cascade Amont 1 & This study & 42.526391 & 2.246652 & 900 & 58 & 9.03 & 317 \\
\hline & Cascade Bas & This study & 42.527219 & 2.245557 & 800 & 72.5 & 9.08 & 323 \\
\hline & Fault spring & This study & 42.527507 & 2.244972 & 800 & 70 & & \\
\hline & Lukas & This study & 42.526956 & 2.242214 & 800 & 43 & & \\
\hline \multirow{3}{*}{ Canaveilles } & Gr. Amont-Rivière & This study & 42.531277 & 2.251046 & 780 & 60.1 & 9.13 & 324 \\
\hline & Gr. Amont-Amont & This study & 42.531723 & 2.250914 & 780 & 43.3 & 9.33 & 302 \\
\hline & Gr. Aval-Figuier & Unpublished data & 42.533360 & 2.255540 & 690 & 52.2 & & \\
\hline \multirow{7}{*}{ Vernet-les-bains } & Du Parc & This study & 42.544510 & 2.389110 & 670 & 54.8 & 9.13 & 299 \\
\hline & Vaporium & This study & 42.543739 & 2.389896 & 670 & 36.1 & 9.23 & 289 \\
\hline & Nathalie & Unpublished data & 42.544170 & 2.390552 & 670 & 47.5 & & \\
\hline & Dr. Defouilloy & Unpublished data & 42.543614 & 2.390550 & 670 & 55.8 & & \\
\hline & Pierre de Berrera & Krimissa 1992 & 42.543739 & 2.389896 & 670 & 46.3 & 9.35 & 413 \\
\hline & Providence & Unpublished data & 42.545390 & 2.391180 & 670 & 40 & & \\
\hline & Charlotte & Unpublished data & 42.543739 & 2.389896 & 670 & 46.1 & & \\
\hline
\end{tabular}

(associated with the Carança segment), and the Canigou Range (associated with the Py segment).

Rocks in the Têt fault hanging wall are mainly Paleozoic metasediments (shales and carbonates) intruded by granite. In the Têt fault footwall, the gneissic dome outcrops under the Paleozoic metasediments, with an average $50^{\circ}$ North-dipping foliation near the fault. The Hercynian ductile fault (CMNC) has the same strike and dip and is crosscut by the Têt fault in the eastern part of the area (see also Figure 4).

Six clusters of hot springs are distributed along the Têt fault, mainly in its footwall (Figures 3 and 4): Llo, Saint-Thomas-les-Bains, Prats-Balaguer, Thues-les-Bains, and Vernet-les-Bains. Canaveilles is the only site located in the hanging wall. These sites may gather one (Llo) or several hot springs; see Table 1 and the following descriptions. These numbers correspond to minimum values because some of the springs are inaccessible or mentioned in archives but currently not found.

The Llo site is located in the western part of the study area (Figure 3), at the Têt fault footwall basal slope-break of the Cerdagne segment, which separates the Puigmal Range from the Mio-Pliocene Cerdagne Basin. There is only one hot spring at the Llo site, with a temperature of $29.1^{\circ} \mathrm{C}$. The Têt fault crosscuts two other faults near the site: a N110E mylonitic reverse fault and a N150E brittle normal fault (the Nuria fault). The hot spring directly emerges in the Têt fault footwall, in a bloc of gneiss delimited by the three abovementioned faults and surrounded by metasediments.

The Saint-Thomas-les-Bains and Prats-Balaguer sites are located in the Têt Valley, $200 \mathrm{~m}$ South of the footwall basal slope-break of the Carança segment fault scarp (Figures 3 and 4(a)). This main fault segment bounds the North of the Carança Range, dominated by high peaks such as the 2677 m Puig Rodon or the more distant $2881 \mathrm{~m}$ high Puig del Geant. The Saint-Thomas-les-Bains site counts five hot springs, with temperatures ranging from $45.3^{\circ} \mathrm{C}$ to $57^{\circ} \mathrm{C}$ (Table 1). They emerge in the gneiss intruded by the MontLouis granite, $50 \mathrm{~m}$ from an unfaulted contact with Paleozoic metasediments (Figure 4). In this zone, three subsidiary brittle faults with strikes of N090E, N120E, and N150E intersect each other. The Prats-Balaguer site (Figures 3 and $4(\mathrm{a})$ ) counts two hot springs (Table 1). Aigues 1 includes two resurgences separated by a few meters both at a temperature of $60^{\circ} \mathrm{C}$, while Aigues 2 has a temperature of $38.7^{\circ} \mathrm{C}$. Although 


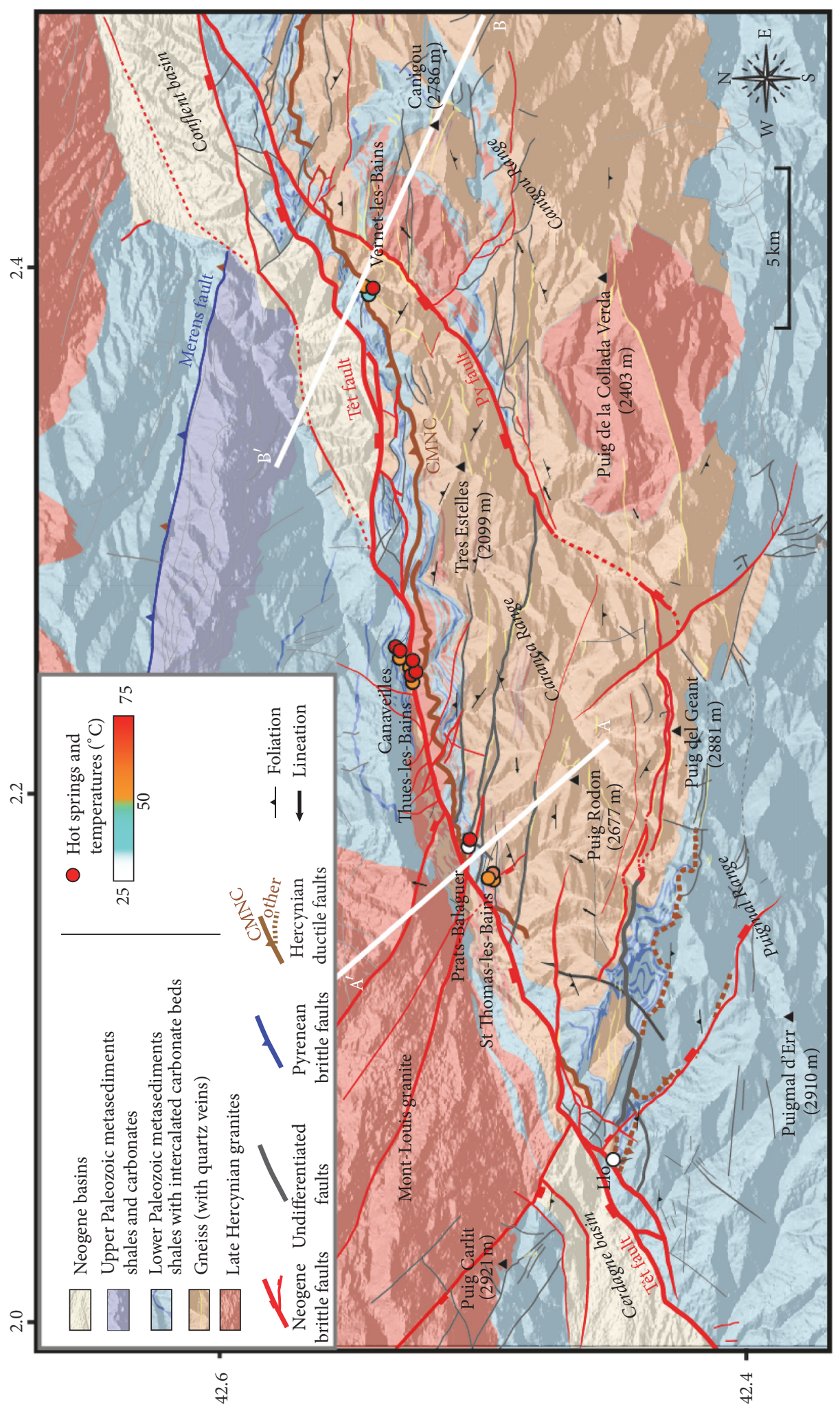

FIGURE 3: Structural sketch of the study area (the Têt Valley), mapping the principal faults, lithologies, and hot springs with temperatures. Six principal clusters are observed, located at the bottom of the Canigou-Carança-Puigmal Ranges, along the brittle Têt fault and the CMNC Hercynian ductile fault. Some of these sites also correspond to the intersection between subsidiary brittle faults with the Têt fault. The location of Figure 4 is noted (white lines). 

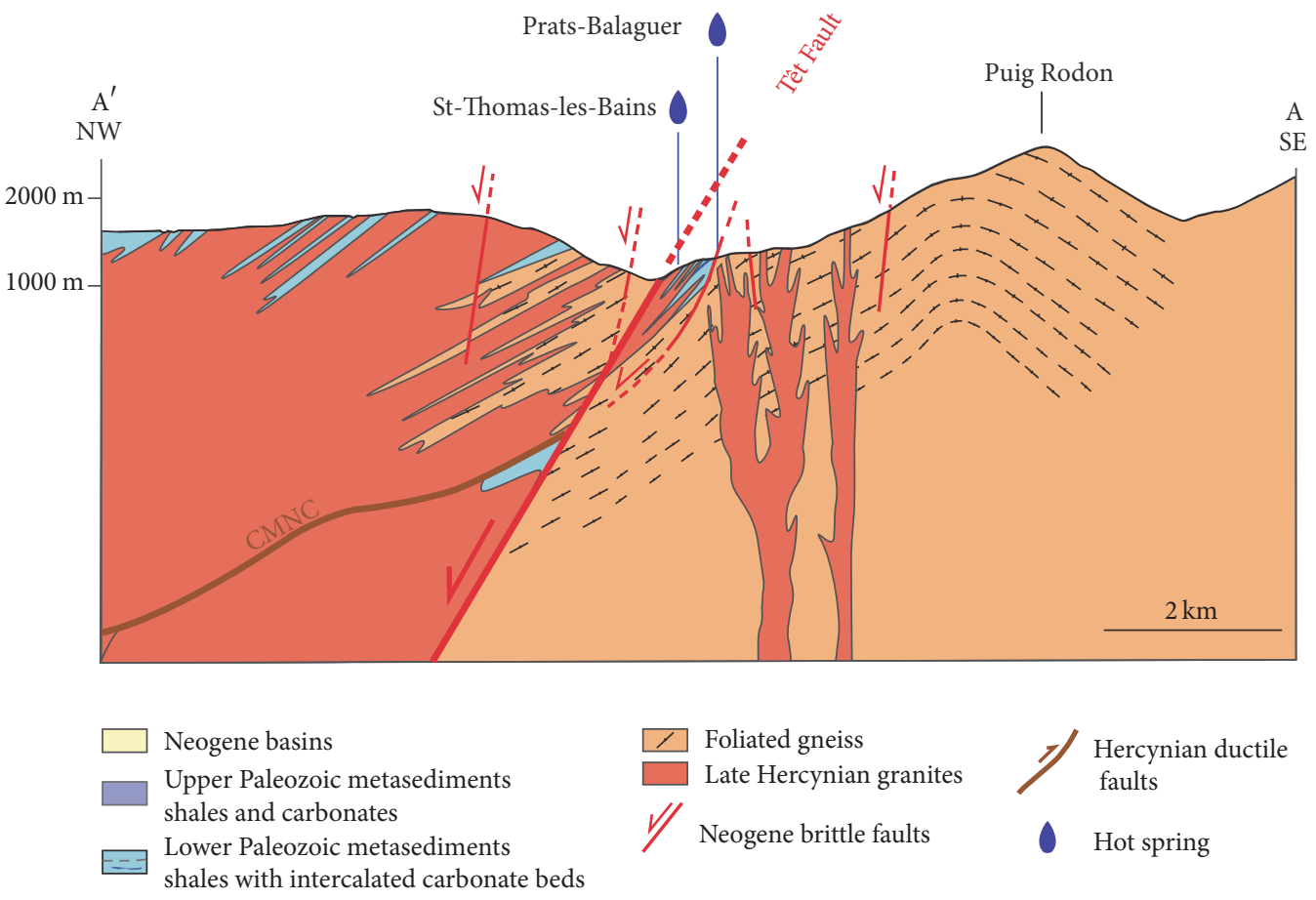

(a)

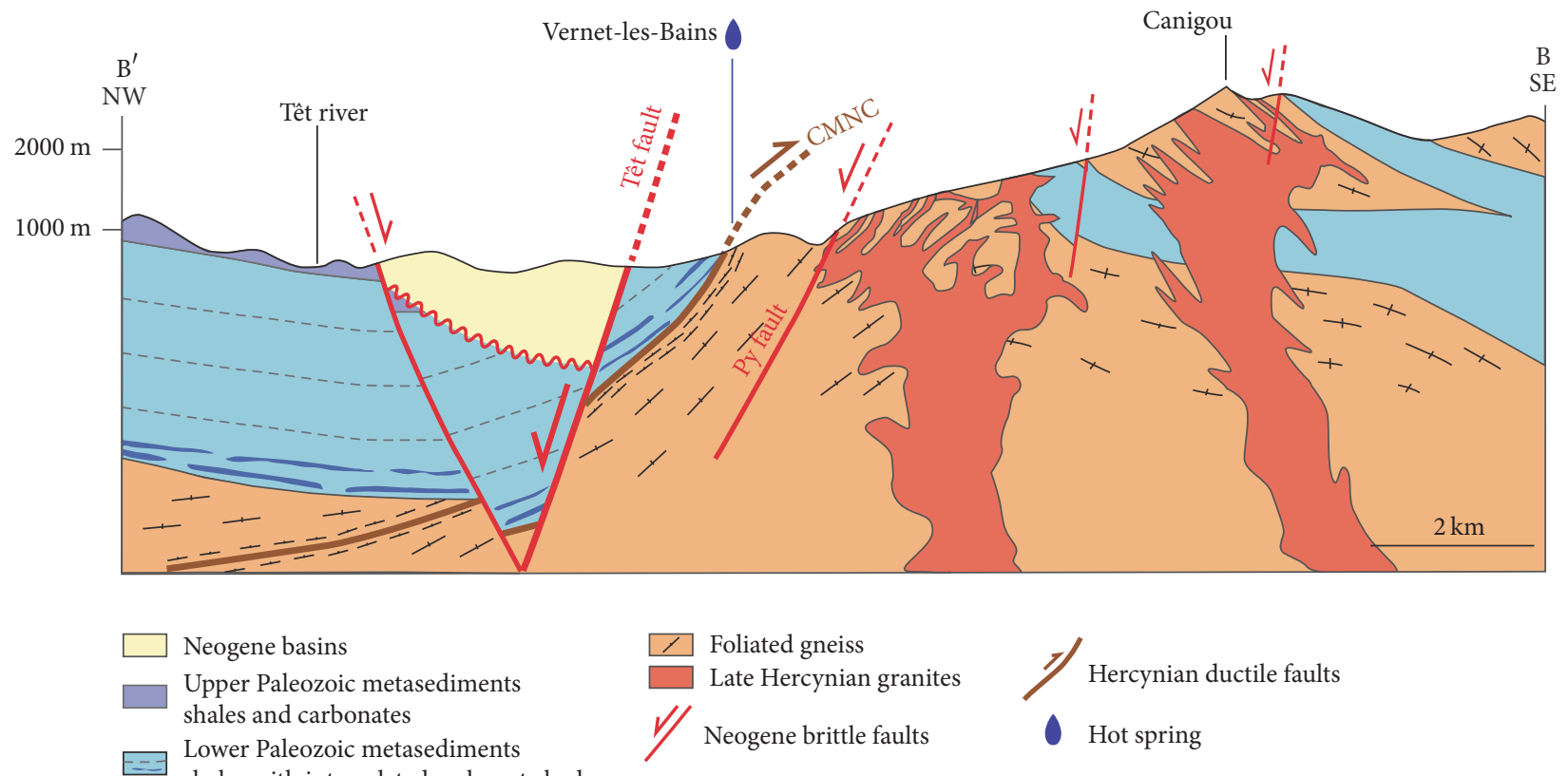

(b)

FIgure 4: Cross-sections indicated on Figure 3. (a) Cross-section of Saint-Thomas-les-Bains and Prats-Balaguer. Hot springs emerge at the base of the Carança Range, in the Têt fault footwall, at an unfaulted gneiss-metasediments contact, close to a subsidiary brittle fault. (b) Crosssection of Vernet-les-Bains. Hot springs emerge at the base of the Canigou Range, on the CMNC ductile fault that juxtaposes metasediments in its hanging wall and gneiss in its footwall. The Têt fault crosscuts the CMNC $1 \mathrm{~km}$ below the surface. 


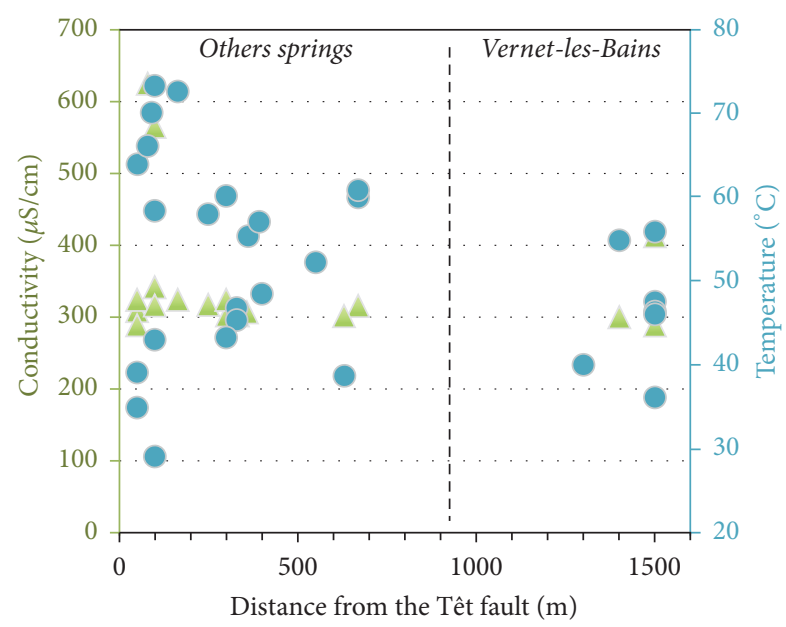

FIGURE 5: Hot spring conductivity (green triangle) and temperatures (blue circles) versus the distance from the Têt fault. Extreme values are in the 200 first meters from the Têt fault (Thues-les-Bains-PratsBalaguer-Saint-Thomas-Bains for the highest, Llo for the lowest). Distant values (>1000 m) correspond to Vernet-les-Bains.

Quaternary screes cover the area, it seems that the spring emerges in the gneiss 20 to $70 \mathrm{~m}$ from a unfaulted contact with metasediments (Figure 4(a)). A N100E brittle fault and a N030E lineament (a subsidiary fault or a fracture corridor) intersect each other near the site.

The Thues-les-Bains site is located around the footwall basal slope-break of the Carança segment fault scarp, bounding the North of the Carança Range (Figure 2). The Têt fault here juxtaposes two blocs of gneiss intruded by granite. At least ten hot springs emerge at the Thues-les-Bains cluster, with temperatures ranging from $35^{\circ} \mathrm{C}$ to $73.2^{\circ} \mathrm{C}$ (Table 1), the latter being the hottest spring in the whole study area. They are mainly located at the intersection between the Têt fault and the ductile CMNC Fault. At least three springs are located $300 \mathrm{~m}$ South of the Têt fault, within the CMNC mylonites.

At the Canaveilles site (Figure 3), two hot springs with temperatures of $43.3^{\circ} \mathrm{C}$ and $60.1^{\circ} \mathrm{C}$ emerge in thinly foliated gneiss (protomylonite), near the unfaulted contact between the gneiss and the metasediments. The Northeastern hot spring (Figuier) with a temperature of $52.2^{\circ} \mathrm{C}$ (Table 1 ) is covered by Quaternary screes but also appears to be located near an unfaulted gneiss/metasediments contact. According to old archive documents, some springs are likely to be located under the abandoned Canaveilles thermal establishment but are currently inaccessible.

The Vernet-les-Bains site is located to the North of the Canigou Peak $(2786 \mathrm{~m}), 1 \mathrm{~km}$ to the South of the Têt fault (Figure 3), between the Têt and Py faults. The springs are located at the bottom of an inverted fault scarp induced by the locally $70^{\circ}$ dipping CMNC ductile fault, which allows juxtaposition of gneiss in the footwall with metasediments in the hanging wall (Figure 4(b)). We count at least seven hot springs with temperatures ranging from $36.1^{\circ} \mathrm{C}$ to $55.8^{\circ} \mathrm{C}$ (Table 1).

Hot spring temperatures and electrical conductivities are plotted in Figure 5 as a function of distance normal to the
Têt fault. Close to the Têt fault, where temperature values are quite spread, it averages $55^{\circ} \mathrm{C}$ and decreases to $47^{\circ} \mathrm{C}$ at $1500 \mathrm{~m}$ further South (corresponding to the Vernet-les-Bains cluster). Extreme temperatures (both highest and lowest) are located at less than $200 \mathrm{~m}$ to the Têt fault, with decreasing temperatures with the distance to the fault. Except at Vernetles-Bains, where emergence is on the CMNC Fault, the hot springs are located at less than $700 \mathrm{~m}$ from the Têt fault.

In summary, the large-scale analysis reveals that the springs generally emerge in crystalline rocks of the footwall (only 3/29 hot springs in the Têt fault hanging wall, that is, at Canaveilles), close to the Têt fault (22/29 hot springs, except Vernet-les-Bains), where extreme temperatures and conductivities are observed. A more precise analysis shows that all the hot springs emerge in crystalline rocks, close to crystalline rock versus metasediment contacts, which seems to be (1) unfaulted contacts (18-21/29 hot springs, at SaintThomas-les-Bains, Thues-les-Bains, Canaveilles, and possibly Prats-Balaguer), (2) ductile fault juxtaposition (7/29 hot springs, exclusively at Vernet-les-Bains), and (3) brittle fault juxtaposition (1-3/29 hot springs, in Llo and possibly PratsBalaguer). Their occurrence seems also favored by ductile faults (24/29 hot springs) or by intersections between the main fault and other Neogene subsidiary brittle faults (9/29 hot spring).

5.2. Faults, Topography, and Spring Emergence. Details of the Têt fault segmentation and associated reliefs are presented in Figure 6(a). Three main segments with a corresponding strike (N060E) compose the Têt fault, from the West to the East: Cerdagne, Carança, and Conflent. The fourth segment of Py-Conflent has a particular N045E strike. These segments correspond to three mountain ranges, limited to the North by the Têt fault, respectively: the Puigmal Range, the Carança Range, and the Canigou Range. This latter is associated with both the Py-Conflent and the Conflent segments. East-dipping significant-subsidiary brittle faults also compartmentalize these three ranges, but to a lesser degree.

Altitude map in Figure 6(b) shows that the Canigou, Carança, and Puigmal Ranges form an elongated high topographic relief with steep slopes, surrounded by low altitude areas. The Canigou Range presents a small surface of highly elevated area, clearly disconnected from the Carança Range by the Py Fault. Conversely, the Carança and Puigmal Ranges form a long and large surface of high elevation, the widest for the Carança Range.

In order to quantify the relation between hot springs and topography (Figure 6(c)), we analyzed twenty-one topographic profiles (locations are detailed in Figure 6(b)) with the following features: (1) in the Têt fault footwall; (2) origin at the Têt fault outcrop; (3) normal to the local Têt fault orientation; (4) $22 \mathrm{~km}$ long. Hot spring temperatures are plotted on the same graph. Green triangles represent the difference between the highest elevation and the Têt fault elevation for each profile, called "the scarp relief" (see the AB profile in Figure 6(b) and the corresponding explanatory cross-section). For each profile, the average normalized altitude integrated to the same length $(22 \mathrm{~km})$ is reported (see 


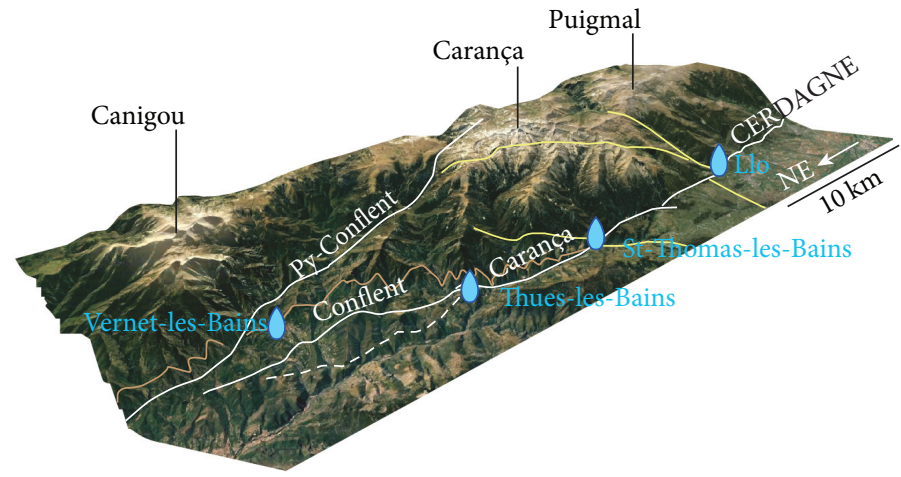

(a)

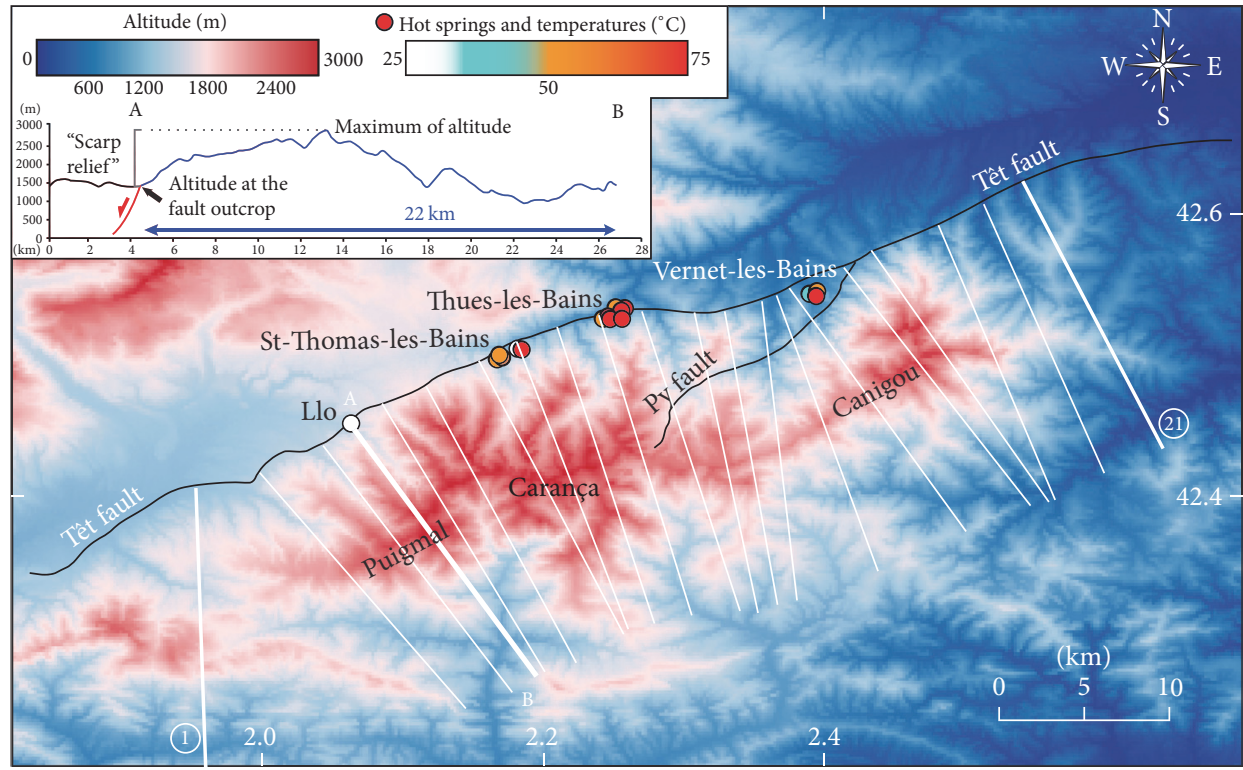

(b)

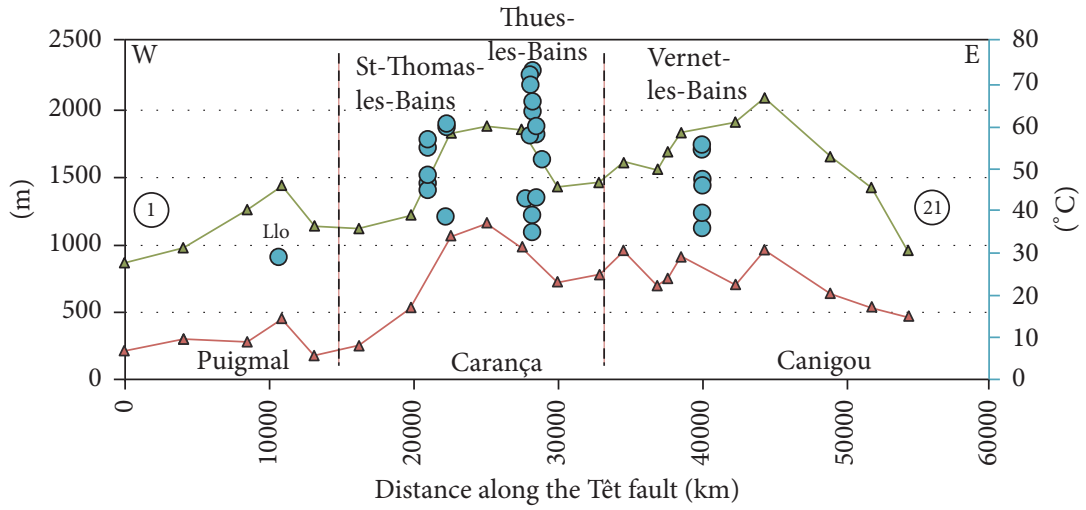

(c)

Figure 6: Relation between hot springs, the Têt fault segmentation, and relief. (a) Location of the main mountain ranges associated with the Têt fault segmentation (white line) and subsidiary faults (yellow line). Principal hot spring sites are indicated. (b) Altitude map including the principal ranges, the Têt and Py faults (black lines), and hot springs with temperatures (colored circles). Springs are at the bottom of high reliefs. The Carança and Puigmal Ranges, concentrating most of the hot springs with the highest temperatures, form a wide area of elevated altitudes compared with the Canigou Range. Numbered profiles used for measurements in (c) are indicated (white lines). (c) Graph along the Têt fault (E-W) of hot spring temperatures (blue circle, right axe), scarp relief (green curve, left axe), and average of normalized altitudes integrated to the range wide (red curve, left axe), calculated from topographic profile (e.g., the A-B cross-section indicated as bold white line in (b)). Profile 1 and profile 21, identified in (b), mark, respectively, the origin and the end of $x$-axis in (c). The highest number of springs and temperature maxima correspond to the largest scarp relief and average of altitudes. 
the average normalized altitudes, red curve, and left axis in Figure 6(c)). The normalization to the Têt fault elevation for each profile is needed because the fault line altitude increases from the East to the West.

The three main ranges (Figures 6(a) and 6(b)) are clearly identified as elevated scarp relief, and conversely the Têt fault relays correspond to the lowest relief. The Canigou and Carança ranges show the largest scarp reliefs. Despite its high altitude, the Puigmal Range is a low scarp relief and the highest scarp relief values for this segment correspond to Llo.

The maximum number of hot springs and temperature at Thues-les-Bains corresponds to the Carança Range, which is characterized by the highest average normalized altitude of the whole area. This parameter allows us to quantify the width (i.e., amplitude of the lateral extent) of the high altitude surfaces above the fault line described in Figure 6(b). The high but not maximum number of hot springs and temperatures in Vernet-les-Bains correspond to the Canigou Range. Associated intermediate values of average normalized elevations correspond to the small extent of high elevation area we previously described in Figure 6(b). Finally, the single low-temperature of the Llo spring corresponds to the Puigmal Range and particularly to a peak of average normalized altitude. This range has the lowest average normalized altitude of the whole area, despite the large surface of high elevations observed on map view (Figure 6(b)).

To summarize, the hot springs are located at the base of a massive relief, showing preferential location with respect to the three ranges: Vernet-les-Bains seems associated with the Canigou Range, Thues-les-Bains and Saint-Thomas-les-Bains with the Carança Range, and Llo with the Puigmal Range. A number of hot springs and temperature distribution are associated with the scarp relief height and specifically to the surfaces of high elevation, linked to segmentation of the Têt fault.

\section{Fault Zones Features}

The location of hot springs is systematically associated with both brittle and ductile faults. This raises the question of the role of fault composition and geometry on fluid upflow. It is therefore worth distinguishing these two potential factors and then also analyzing brittle and ductile fault zone constitution.

6.1. Brittle Fault Zones. The Têt fault outcrops at the Llo thermal resort parking (Figure $7(\mathrm{a})$ ) where gneisses are juxtaposed to metasediments and at the Thues-les-Bains train station (Figure $7(\mathrm{~b})$ ) where the fault zone juxtaposes gneiss against gneiss. Supplementary materials give panoramic images of the whole fault zones, microscopic images of the fault and host rock textures, and results of XRD analysis of sinters and cement encountered in the whole study area (see Supplementary Material available online at https://doi.org/10.1155/2017/8190109).

The Têt fault outcrop at Llo (Figure $7(\mathrm{a})$ ) is $30 \mathrm{~m}$ long. We estimate the whole fault zone to be $90 \mathrm{~m}$ wide using aerial pictures, but only the contact between the core zone and the footwall damage zone clearly outcrops. The fault trace is marked in the landscape by an abrupt topography drop. The scarp bottom corresponds to a marked and smooth fault plane juxtaposing the core zone constituted of cataclastic fault rocks with fractured gneiss in the footwall damage zone. The Têt fault is a multicore fault composed of smaller cataclastic fault zones, principally E-W oriented and mostly synthetic to the main fault, alternating with highly fractured gneiss lenses. The fault rocks are composed of cataclastic breccias to ultra-cataclasites [83]. As seen in Figure 2, the Têt fault here juxtaposes metasediments dipping $20^{\circ}$ to the North in the hanging wall with highly fractured gneiss dipping $50^{\circ}$ to the North in the footwall. Measured fractures in the damage zone show three principal strikes: N-S, E-W, and NE-SW. The E-W and NE-SW fractures dip to the North, and the N-S fractures principally dip to the East (asymmetrical rose diagram in Figure 7 gives information about dip direction, always located on the left of the represented strike, right hand rule). Most of these fractures are subvertical, open, and uncemented. They crosscut each other and also fractures parallel to the gneissic foliations. The Llo hot spring emerges in these fractured gneisses in the footwall damage zone.

The Têt fault at Thues-les-Bains (Figure 7(b)) is a $15 \mathrm{~m}$ wide multicore fault (against $90 \mathrm{~m}$ in Llo). Two principal fault planes separate the wide multicore zone from the damage zone, which are both composed of gneiss. Smaller fault planes separate gneiss lenses and the smaller zones of protocataclasite to cataclasite. All these faults localize millimetric to centimetric bands of cataclasite, with at least $60 \%$ fine matrix composed of quartz, carbonate, and locally chlorite, in association with opaque mineral (probably oxides). Quartzveins crosscut calcite-veins, and both of them crosscut the whole cataclastic textures (see Supplementary Materials). Fault strikes range between N080E and N130E, dipping $70^{\circ}$ to the North or the South, and show evidence of normal slip. We also observe some N-S trending slip planes. A white sinter, mainly composed of quartz and additionally white micas and albite, covers the fault planes, especially those separating the multicore zone with the damage zones. Such cement seals numerous fractures in damage zones (see Supplementary Material), especially at Thues-Entre-Valls, located $2 \mathrm{~km}$ west of Thues-les-Bains, where the Têt fault outcrops but no hot springs emerge. Gneisses in damage zones are highly fractured, in particular within the first $3 \mathrm{~m}$ out the multicore zone. The fractures record two principal strikes: N120E to N140E and N040E (as in Llo), in both cases dipping $70^{\circ}$. The NE-SW fractures are widely represented by large surfaces dipping to the South (synthetic to some fault planes observed in the core zone). The hot springs mainly emerge in the footwall damage zone and spread over $200 \mathrm{~m}$ from the Têt fault. Some springs emerge in the hanging wall at few hundred meters to the North of this outcrop (Canaveilles springs, Figure 2).

6.2. Ductile Fault Zones. Ductile fault as the CMNC also shows evidence of fluid circulation. At one hundred meters from the Vernet-les-Bains thermal resort (Figure 8(a)), decimeter-size elongated cavities are aligned along the mylonitic foliation of the CMNC, which here dips very steeply $\left(70^{\circ}\right)$. The hot springs in Vernet-les-Bains emerge 


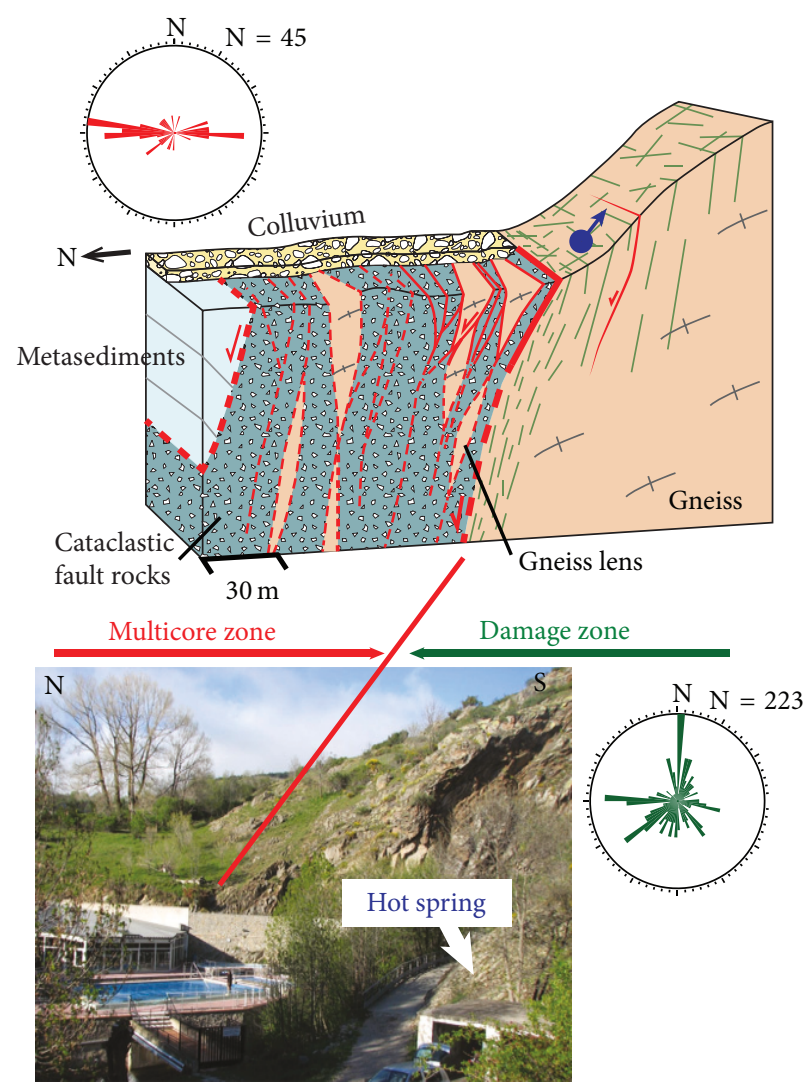

(a)
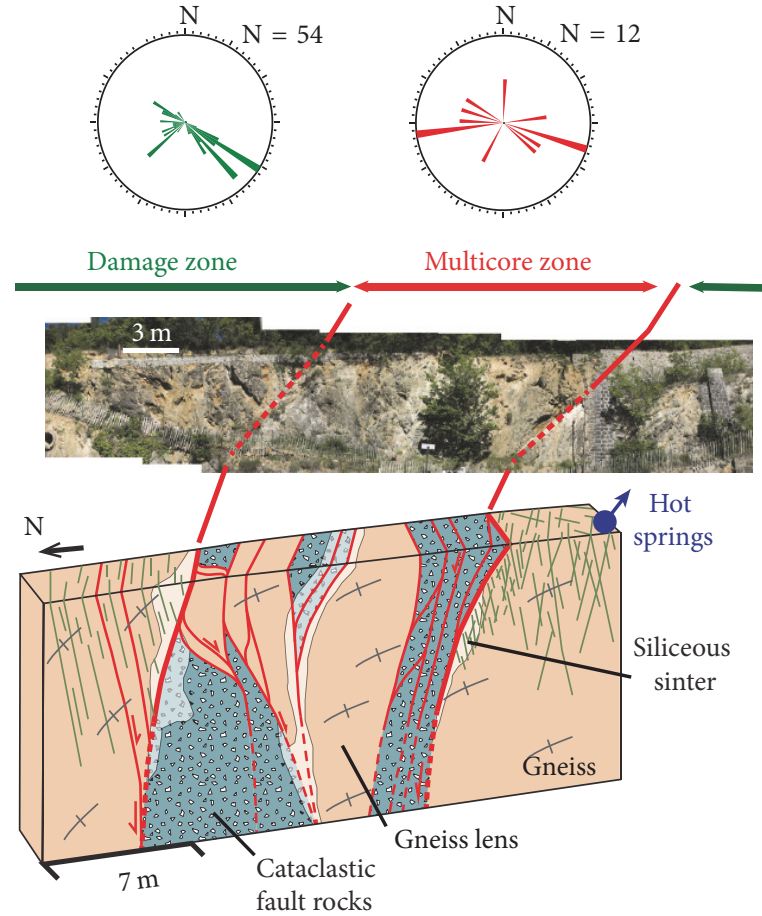

(b)

Figure 7: Two outcrops of the brittle Têt fault. Red rose diagrams represent fault plane principal strike (to the right of dip direction, explaining the diagram asymmetry) in the multicore zone, whereas green rose diagrams represent fracture strikes in the damage zone. (a) Llo hot spring site. The visible part of the outcrop (continuous line) shows that the Têt fault is a multicore fault of gneiss lenses separated by many fault planes of cataclastic fault rocks. The hot spring emerges in the Têt fault footwall damage zone. Gneiss in the footwall is juxtaposed with metasediments in the hanging wall. (b) Thues-les-Bains hot spring site. In the multicore zone, $30 \mathrm{~m}$ wide, many fault plans covered by white mineralizations separate large gneissic lenses from the cataclastic rocks. Highly fractured gneiss constitutes both the hanging wall and the footwall damage zones, where the hot springs emerge.

in feldspar-rich gneiss with minor muscovite (Figure 8(b)). Chlorite and opaque minerals (probably oxides) are localized along the mylonitic foliation and are crosscut by carbonate veins. Sinter of harmotome, a zeolite produced by hydrothermal alteration of igneous rocks around $200^{\circ} \mathrm{C}$ [84], surrounds the hot springs and cavities.

Near the hot springs in Canaveilles (Figure 8(c)), similar cavities (Figure 8(a)) are aligned along the thinly foliated gneiss (practically a mylonite). They are located at the intersection between the foliation and subvertical uncemented joints of centimeter length. These cavities are surrounded by white halo, whose composition could not be identified.

In summary, in Llo and Thues-les-Bains, the Têt fault controls the lithology juxtaposition (gneiss versus metasediments or gneiss versus gneiss), as well as the high-density, strike, and intersection of uncemented fractures in the damage zone, where studied hot springs are located. Concerning rocks of the multicore fault zone, cataclastic rocks are always present, even in poorly damaged rocks, such as gneiss lenses between cataclastic zones. Ductile fault zones (mylonites) show elongated cavities along the foliation, showing evidences of fluid circulations. Quartz and carbonates veins always crosscut brittle fault rocks or structures and sometimes are localized along the gneissic foliation.

\section{Numerical Models of the Têt Hydrothermal Circulations}

We combine the maximum of topography and hydrothermal activity (Section 5.2) with core zone constitution and damage zone fracturing of the Têt fault (Section 6.1) in a numerical model of hydrothermal circulation at Thues-les-Bains (Figure 9).

7.1. Model Set-Up. The McKenna and Blackwell method we reproduced in a benchmark (Section 4.2) is applied to the Têt Valley with geometry adapted to get closer to our field example at Thues-les-Bains/Canaveilles, where the number of hot springs and temperatures are the highest (Table 1). Our model is $20 \mathrm{~km}$ long (in order to limit side-effects) and 


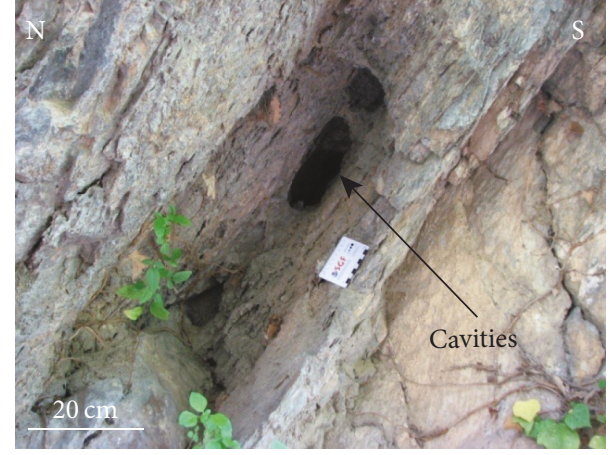

(a)

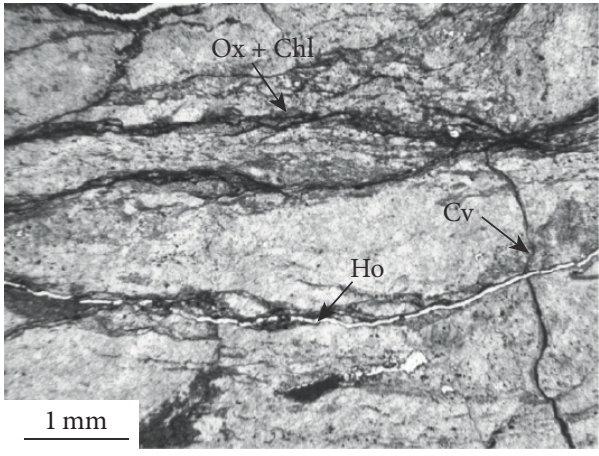

(b)

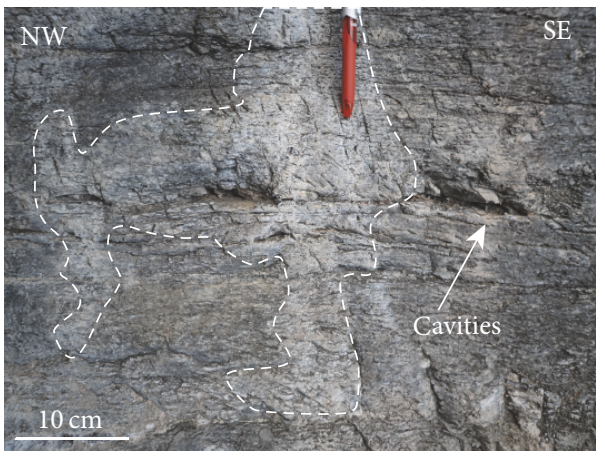

(c)

FIGURE 8: Ductile fault outcrops and thin sections. (a) Vernet-les-Bains mylonitic outcrop with foliation parallel dissolution cavities. (b) Vernet-les-Bains gneiss thin section showing a hole (Ho) parallel to the foliation crosscutting a carbonate vein (Cv). Oxides and chlorite (Ox $+\mathrm{Chl}$ ) localize along the foliation. (c) Dissolution cavities along the fractured gneissic foliation at Canaveilles hot springs. Doted white line surround mineral deposit.

extends over $5 \mathrm{~km}$ below the surface. The simplified topographic profile at Thues-les-Bains is reproduced, inducing a topographic gradient of $1650 \mathrm{~m}$ for the southern mountain range, against $500 \mathrm{~m}$ for the northern range. Based on field observations (Section 6), a fault zone dipping $70^{\circ}$ to the North is added at the base of the southern mountain range. Two $100 \mathrm{~m}$ wide damage zones surround the $30 \mathrm{~m}$ wide core zone.

These compartments have distinct permeabilities against the rest of the crust. Because hydrothermal fluids only circulate in crystalline rocks (Section 4 [50]) and considering that the permeability of this kind of rocks is strongly influenced by its fractured state [85], we use a typical permeability of gneiss $\mathrm{Kg}=10^{-16} \mathrm{~m}^{2}$ for the host rocks. Similar models [19] show that the highest spring temperatures are obtained with this value. Permeability of the fault zone corresponds to those measured in laboratory tests [86] and to those previously used in similar models $[77,87,88]$. A permeability of $K c=10^{-18} \mathrm{~m}^{2}$, such as the one observed in thin cataclastic textures [89], is applied to the core zone. The same permeability of $K d=$ $10^{-14} \mathrm{~m}^{2}$ is applied to the two lateral damage zones. Damage zones are areas of highly fractured host rocks able to greatly enhance the permeability [27].

The surface temperature is $20^{\circ} \mathrm{C}$ and we apply a vertical geothermal gradient of $30^{\circ} \mathrm{C} / \mathrm{km}$ (an average value, also used by McKenna and Blackwell). To simulate emergence of hot fluid at the surface, a convective flux condition (isotherms are fixed normal to the surface) was imposed at the top of the fault, to allow the recording of discharge temperatures.

7.2. Results. At the beginning of the simulation, the thermally conductive regime is computed with small permeability values, preventing any fluid circulation. Then, switching on the permeability changes this initial conductive regime, and transient evolution is recorded during 100 kyrs. Figure 9(a) shows the steady state of our experiment, achieved after around 40,000 years. This time scale matches with residence times of the current hydrothermal water [50] and with those observed by McKenna and Blackwell [11].

Temperatures range between $20^{\circ} \mathrm{C}$ on the surface and $170^{\circ} \mathrm{C}$ at the base of our model (Figure 9(a)). Meteoric fluids flow from the top of the ranges to the valleys, where isotherms rise. This phenomenon is particularly enhanced at the proximity of the Têt fault and less significantly marked for the left edge of the model (South of Carança), which does not involve a fault.

A zoom on the Têt fault near the surface (Figure 9(b)) shows how high the isotherms are upraised in the fault zone. For example, the $80^{\circ} \mathrm{C}$ isotherm, which is around $3000 \mathrm{~m}$ below the surface of the highest peak of the range (Figure 9(a)), rises to $300 \mathrm{~m}$ below the local surface (at $1100 \mathrm{~m}$ of altitude) within the damage zone (1900 m of upwelling). 


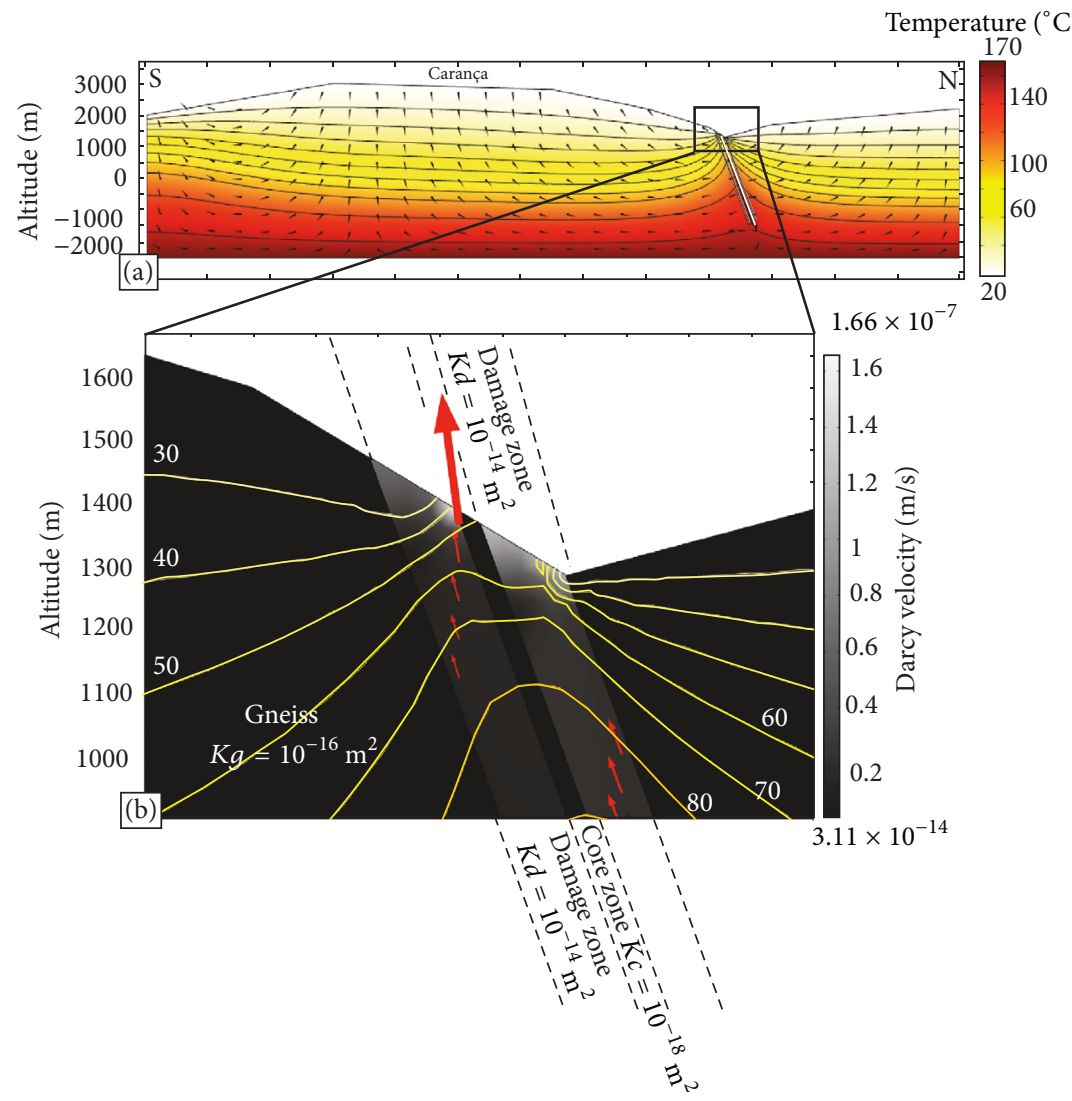

FIgURE 9: Preliminary numerical model of the Têt hydrothermal fluid circulations, performed with COMSOL Multiphysics ${ }^{\mathrm{TM}}$ software. Bedrock (gneiss) permeability $=10-16 \mathrm{~m}^{2}$; core zone permeability $K c=10-18 \mathrm{~m}^{2}$. Damage zone permeability $K d=10-14 \mathrm{~m}^{2}$. The large-scale cross-section represents thermal and velocity fields for the Canigou-Carança Range at Thues-les-Bains. Isotherms rising around the Têt fault are observed (a). (b) Zoom on the fault zone in (a) with spatial evolution of Darcy velocity (black and white color scale) and isotherms (yellow to orange lines). High velocities concentrate in the damage zone, at the interface with the core zone. Fluids with temperatures exceeding $50^{\circ} \mathrm{C}$ reach the surface.

The highest fluid velocities $\left(1.6 \times 10^{-7} \mathrm{~m} / \mathrm{s}\right)$ are in the two damage zones (Figure 9(b)). Fluid velocities at the surface are lower in the hanging wall than in the footwall. The maximum fluid velocity is at the interface between the footwall damage zone and the core zone, near the surface. The temperature obtained for this maximum velocity at the surface is around $50^{\circ} \mathrm{C}$. Surface temperatures vary between $30^{\circ} \mathrm{C}$ and $50^{\circ} \mathrm{C}$ with a temperature decrease from the core zone toward the gneissic bedrock. Note that the absolute value of temperature at the emergence depends on permeability values of the fault and of the host rocks, previously demonstrated [78]. Our results must thus be considered as plausible mechanisms that could reproduce in situ hot spring features in adjusting permeability values. It must be pointed out that the timescales (tens of thousands years) correspond to estimated values by geochemistry (Section 3 ) and that typical hot springs temperatures were obtained with no additional heat source.

\section{Discussion}

Because of its location in a Neogene normal fault in the Pyrénées, the Têt hydrothermal system is hybrid between orogenic belt [7] and extensional types [2], without magmatic heat source (Section 7.2). Figure 10 summarizes our observations together with the results of our numerical models and following discussions, in a conceptual model of hydrothermal fluids upflow around the Têt fault. It is worth distinguishing the factors controlling the whole hydrothermal activity (elevated infiltration areas, scarp relief) from those controlling the hot spring locations (brittle fault architecture and composition, ductile fault, and crystalline rocks versus metasediment contacts), although most are related to the presence of the Têt normal fault.

8.1. Controls on the Hydrothermal Activity. The distribution of the hydrothermal activity (hot spring number and temperatures) in relation to the fault scarp relief (Section 5.2) suggests that footwall topography is an essential parameter allowing recharge and hydrothermal fluid circulation path [10]. This study constrains these processes with in situ data while they have been exclusively explored by numerical modeling before [19].

Based on oxygen isotopes [50], elevated surfaces have been identified as being the infiltration areas of meteoric water (Figure 10). The high reliefs of Canigou, Carança, and Puigmal are the only candidates for infiltration areas [10], 


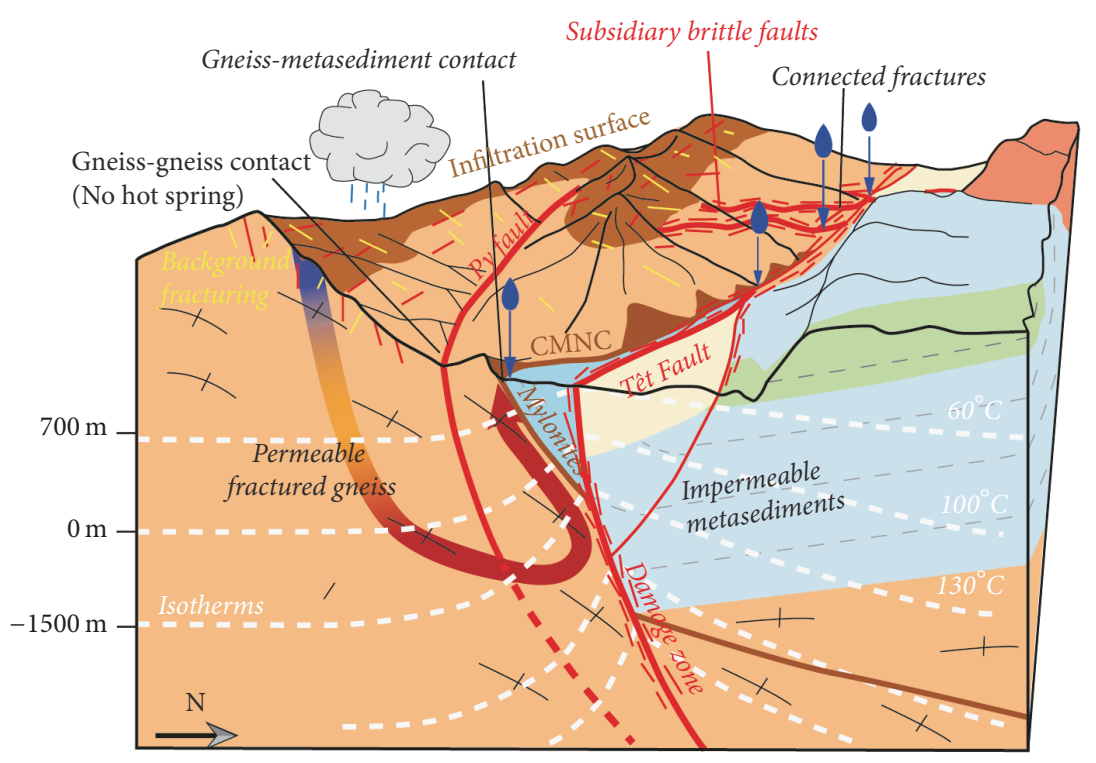

Figure 10: Conceptual model of hydrothermal circulations in the Têt Valley. Meteoric water infiltrates on the Canigou-Carança Range, using background or fault-related fractures, to warm in one or more shallow hot reservoirs, existing because of the influence of the Têt fault on isotherms. They use fractures in the Têt fault damage zone as pathway to the surface, preferentially at the intersection between the Têt fault damage zone with subsidiary brittle faults or ductile faults. Gneiss-metasediments contacts and/or impermeable cataclasites in the core zone restrict fluids in the Têt fault footwall. The Py brittle fault, juxtaposing gneiss in its two compartments, localize no hot springs, and maybe compartmentalizes fluids at shallow depths.

because mountains in the Têt fault hanging wall are not high enough. Intense hydrothermal activity corresponding to large elevated surfaces (Figure 6) suggests that footwall elevation above the fault scarp bottom likely controls volume of meteoric water infiltrated on the ranges [10, 19], which should influence flow rates at the emergence. Further, high scarp relief is likely to induce a high hydraulic gradient, allowing high fluid velocities and infiltration depths (Section 7) [19]. The fault-related topography, being essential to establish fluid advection [10,18], also controls the intensity of the hydrothermal activity (Figure 6).

The almost exclusive location of hot spring in the footwall implies that the Têt hydrothermal system, including a reservoir and a fluid loop, should lie underneath the footwall relief (Figure 10). Based on water geochemical analyses, Krimissa [50] concludes that the Vernet-les-Bains, Thues-les-Bains, and Saint-Thomas-les-Bains hot springs are likely sourced from a unique reservoir. However, both relief compartmentalization related to the Têt fault segmentation, in particular the Py fault (see Figure 6), and differences of sinter compositions (see XRD analysis in Supplementary Material) question the presence of a unique convection cell and suggest the existence of a separate one underneath the Canigou Range related to the Vernet-les-Bains hot springs (Figure 10).

\subsection{Controls on Hot Spring Location}

8.2.1. Brittle versus Ductile Faults. Brittle fault architecture, with respect to composition of core zones and density, opening, and connectivity of fractures in damage zones, likely controls hydrothermal fluid upflow and pathways. This has often been demonstrated at a map scale $[1,8]$, but more rarely at the outcrop or microscopic scale $[14,15]$. Fault damage zones in gneiss appear important for localizing hydrothermal fluid upflow. Highly concentrated fractures in the Têt fault damage zone (Figure 8) are an efficient vertical pathway $[27,36,90]$, previously identified in a similar hydrothermal system [16]. Fractures with Têt fault strikes (NE-SW) concentrate in its damage zone and are also represented at a regional scale [53]. Subsidiary NW-SE brittle faults (Figure 2) concentrate similarly oriented fractures in their damage zones. Intersections of the Têt fault and the NW-SE faults damage zones enhance fracture connections and favor the formation of efficient drains for fluids rising [1, 14, 41] (Figure 10). The temperature-dependence of fluid density induces a buoyancy force allowing hydrothermal fluids to upflow using the highly fractured Têt fault damage zone and subsequently causing isotherm uplift (Figure 10). Our models improve the McKenna and Blackwell ones [11] taking into account a compartmentalized fault. The complex pathway due to fault zone heterogeneity and fracture interconnections probably impact the amount of heat loss during the fluid ascent [10]. Secondary less efficient pathways issue from a principal one could explain the variability of hot springs temperatures in surface (Figure 4). Thus, decrease of hot spring temperature and disappearance of hot springs could be related to the permeable damage zone thickness (here, $200 \mathrm{~m}$ to $700 \mathrm{~m}$ ).

High matrix content in cataclasite of the Têt fault core may form an impermeable barrier for ascending fluids [27, 36 , 91], restricting them in the footwall (Figure 10), as 
suggested by the numerical models (Section 7). However, the multicore architecture of the Têt fault may complicate forecasting of fluid pathways, depending on the thickness and matrix content of cataclastic cores, and connections of damaged gneiss lenses [28, 92]. The small size of the core zones and large thicknesses of damaged connected gneiss at Thues-les-Bains may explain the exceptional presence of hot springs in the hanging wall in Canaveilles.

The occurrence of hot springs along the CMNC mylonites in the footwall far from the Têt fault (Vernet-les-Bains) indicates that ductile faults may be efficient permeable pathways allowing fluid upflow to deviate from the fault damage zone (Figure 10). Dissolution cavities in mylonites, which have never been described before, and fractures aligned along the foliation, if generalized and connected along the whole ductile fault, likely induce high permeability anisotropic pathway. Gneiss and mylonite foliations have anisotropic tensile strength related to weak phyllosilicates preferentially oriented along deformations planes [93]. Foliation planes could therefore be open because of the past or current in situ stress. The Oligo-Miocene NW-SE extension, responsible for the Têt fault, is well oriented for inducing a part of dilatancy along the $50^{\circ} \mathrm{N}$-dipping foliation. Overpressurized hot fluids of low viscosity, sealed below juxtaposed impermeable metasediments, may enhance the phenomenon in flowing along the foliation. This must favor fracturing along the foliation and mineral dissolution allowing subsequent cavities to develop. This type of fluid flow in shear zones has been inferred [94] as being enhanced by a postdeformation sericite alteration of feldspars, which can also weaken the rock. The role of exhumed shear zones on active hydrothermal systems has only been discussed before by Belgrano et al. [14]. Their conclusions about the sealant effect of mylonites strongly differ from our observations; however their hydrothermal system and geological context are different than the Têt fault system and do not involve metasediment juxtaposition.

Siliceous sinter around cavities and hot spring are likely related to hydrothermal precipitation [8]. Cement of similar composition filling fractures in the Têt fault damage zone away from the actual hot springs (e.g., Thues-entre-Valls) could attest to abandoned paleoemergence [26]. Deposition of such hydrothermal minerals can therefore progressively seal fractures in the damage zone and thus fluid flow pathways $[17,95]$. However, optimally oriented in situ stresses can prevent fractures from sealing, maintaining permeability [34, $46,96,97]$. Previously sealed fractures may also be reactivated under such conditions, reactivating fluid upflow [47]. The orientation of the regional stress in the Eastern Pyrénées is currently not well constrained [58, 66, 68], but there is moderate regional seismicity [49] suggesting nonnegligible present-day stress, which when assisted by fluid pressure may reactivate fractures and fault surfaces $[1,11,98]$. Depending on sealing by hydrothermal alteration and opening by in situ stress, the Têt fault permeability is a time-dependent parameter [90].

8.2.2. Gneiss-Metasediments Contacts. Hot springs emerging systematically in crystalline rocks suggest that fluids should only flow in crystalline rocks [50] (Figure 10). The emergence being exclusively located close to a contact (faulted or not) between crystalline rocks and metasediments means that these contacts should act as barriers to fluid flow, whereas fractured gneiss or mylonites act as pathways [99]. This has never been highlighted in other studies of extensional hydrothermal system. Where the Têt fault crosscuts gneissmetasediments contacts $1 \mathrm{~km}$ below the surface (Figure 4), hot fluids are likely diverted from the Têt fault damage zone explaining why some emergence is distant to the Têt fault (Vernet-les-Bains, Saint-Thomas-les-Bains; see Figure 10). The lack of hot spring along the Py fault and the exceptional presence of hot springs in the Têt fault hanging wall in Canaveilles, in both cases juxtaposing gneiss versus gneiss, confirms the need of this sealing contact to constrain fluids in the Têt fault footwall.

\section{Conclusion}

In providing integrated mapping and field data of the Têt hot springs, this study gives constraints for numerical models and thus a better comprehension of fault-related controls on this type of hydrothermal system.

The intensity of the hydrothermal activity (amount and temperature of the hot spring) is linked to (i) the height of the Têt fault scarp, allowing large hydraulic gradient responsible for fluid transfer inside the range, as shown in numerical models; (ii) the surface of high elevation, corresponding to the recharge areas of meteoric water. These factors are related to the footwall topography, which is controlled by the Têt fault offset and segmentation.

Despite occasional overlapping and likely combination of processes, the fault-related factors favoring hot springs distribution have been identified and prioritized according to their occurrence:

(i) The lithological control appears to be major for hot springs location: in all sites, they emerge in crystalline rocks, at faulted or unfaulted contacts between crystalline rocks and metasediments. This key factor has rarely been identified for hydrothermal system in basement rocks. Brittle and ductile faults may play a role in the hot spring distribution in controlling lithology juxtaposition.

(ii) Twenty-six out of twenty-nine hot springs are in the Têt fault footwall, generally located close to intersections with subsidiary brittle faults. At these locations, fault damage zones intersect, and hence, fracture density and connectivity are the highest. As shown by numerical modeling, damage zones are permeable pathways allowing fluids upflow from depth and resulting in isotherms upwelling.

(iii) Twenty-four out of twenty-nine hot springs are located along a mylonitic ductile fault where dissolution cavities align along the foliation. Ductile faults provide gneiss-metasediment juxtaposition and localize fluid flow along the foliation, allowing hot springs to emerge far from the Têt fault damage zone (Vernet-les-Bains). This shows for the first time that mylonitic ductile fault may represent a more efficient 
pathway for hydrothermal fluids than fault damage in metasediments.

(iv) The cataclasite being present between permeable gneiss lenses in the Têt fault core zone probably acts as baffles favoring hydrothermal fluid flow in the footwall. However, because of the presence of three hot springs in the hanging wall (Canaveilles) and the lack of hot spring along the Py Fault, the sealant properties of these cataclastic core zones, when juxtaposing gneiss versus gneiss, could be discussed.

The overview of the factors favoring hydrothermal fluid pathways and hot spring distribution has strong implications for geothermal exploration. Hydrothermal systems with faults in basements rocks and elevated topography deserve to be explored in the light of the above. In order to confirm our conclusions, similar integrated study should be carried out through other nonmagmatic hydrothermal systems. Meanwhile, numerical models should be developed to integrate the complexity of the lithology, topography, fault structure, and permeability.

\section{Disclosure}

Part of this work was presented in poster form and corresponding abstract to the European Geosciences Union General Assembly 2017. Guillaume Martin was previously affiliated to Géosciences Montpellier.

\section{Conflicts of Interest}

The authors declare that there are no conflicts of interest regarding the publication of this paper.

\section{Acknowledgments}

Thanks are due to Clare Bond whose constructive comments helped to improve the paper. This work corresponds to one part of a Ph.D. thesis included in the RGF (Référentiel Géologique de la France) project led by the BRGM, which the authors acknowledge for its financial and technical support. The authors wish also to thank K. Valera, J. Villard, and P. Y. Bres for their participation in the field campaign, B. Celerier for the explanations about the FSA software, P. Labaume and $\mathrm{A}$. Chauvet for thin sections interpretations, and $\mathrm{B}$. Ladouche and G. Vasseur for the interesting discussions about geochemistry and hydrothermal systems.

\section{References}

[1] D. Curewitz and J. A. Karson, "Structural settings of hydrothermal outflow: Fracture permeability maintained by fault propagation and interaction," Journal of Volcanology and Geothermal Research, vol. 79, no. 3-4, pp. 149-168, 1997.

[2] I. S. Moeck, "Catalog of geothermal play types based on geologic controls," Renewable and Sustainable Energy Reviews, vol. 37, pp. 867-882, 2014.

[3] V. Bouchot, H. Traineau, L. Guillou-Frottier et al., "Assessment of the bouillante geothermal field (guadeloupe, french west indies): toward a conceptual model of the high temperature geothermal system," in Proceedings of the World Geothermal Congress, Bali, Indonesia, 2010.

[4] P. Grimaud, J. Richter, J. Rolet et al., "Fault geometry and extension mechanisms in the central Kenuya rift, East-Africa-A 3D remote-sensing approach," Bulletin des Centres de Recherches Exploration-Production Elf Aquitaine, vol. 18, pp. 59-92, 1994.

[5] R. Cioni, G. Fanelli, M. Guidi, J. K. Kinyariro, and L. Marini, "Lake Bogoria hot springs (Kenya): geochemical features and geothermal implications," Journal of Volcanology and Geothermal Research, vol. 50, no. 3, pp. 231-246, 1992.

[6] A. Genter, K. Evans, N. Cuenot, D. Fritsch, and B. Sanjuan, "Contribution of the exploration of deep crystalline fractured reservoir of Soultz to the knowledge of enhanced geothermal systems (EGS)," Comptes Rendus - Geoscience, vol. 342, no. 7-8, pp. 502-516, 2010.

[7] S. E. Grasby and I. Hutcheon, "Controls on the distribution of thermal springs in the southern Canadian Cordillera," Canadian Journal of Earth Sciences, vol. 38, no. 3, pp. 427-440, 2001.

[8] J. E. Faulds, M. Coolbaugh, V. Bouchot, I. Moek, and K. Oguz, "Characterizing structural controls of geothermal reservoirs in the Great Basin, USA, and Western Turkey: developing successful exploration strategies in extended," in Proceedings of the World Geothermal Congress, pp. 25-29, Paris, France, 2010.

[9] R. Sonney and F.-D. Vuataz, "Numerical modelling of Alpine deep flow systems: A management and prediction tool for an exploited geothermal reservoir (Lavey-les-Bains, Switzerland)," Hydrogeology Journal, vol. 17, no. 3, pp. 601-616, 2009.

[10] F. Velard, "Modeles simples de comportement dune source deau chaude," Essai D’Application Aux Sources Thermales de la Haute Vallée de la Têt (Pyrénées Orientales), 1979.

[11] J. R. McKenna and D. D. Blackwell, "Numerical modeling of transient Basin and Range extensional geothermal systems," Geothermics, vol. 33, no. 4, pp. 457-476, 2004.

[12] D. Benoit, "Conceptual models of the dixie valley, nevada geothermal field," in Proceedings of the GRC Transactions. Geothermal Resources Council, pp. 505-512, 1999.

[13] C. Wanner, L. Peiffer, E. Sonnenthal, N. Spycher, J. Iovenitti, and B. M. Kennedy, "Reactive transport modeling of the Dixie Valley geothermal area: Insights on flow and geothermometry," Geothermics, vol. 51, pp. 130-141, 2014.

[14] T. M. Belgrano, M. Herwegh, and A. Berger, "Inherited structural controls on fault geometry, architecture and hydrothermal activity: an example from Grimsel Pass, Switzerland," Swiss Journal of Geosciences, vol. 109, no. 3, pp. 345-364, 2016.

[15] J. S. Caine, R. L. Bruhn, and C. B. Forster, "Internal structure, fault rocks, and inferences regarding deformation, fluid flow, and mineralization in the seismogenic Stillwater normal fault, Dixie Valley, Nevada," Journal of Structural Geology, vol. 32, no. 11, pp. 1576-1589, 2010.

[16] S. T. Nelson, A. L. Mayo, S. Gilfillan et al., "Enhanced fracture permeability and accompanying fluid flow in the footwall of a normal fault: The Hurricane fault at Pah Tempe hot springs, Washington County, Utah," Bulletin of the Geological Society of America, vol. 121, no. 1-2, pp. 236-246, 2009.

[17] C. B. Forster, J. S. Caine, S. Schulz, and D. L. Nielson, "Fault Zone Architecture and Fluid Flow an Example From Dixie Valley, Nevada," in Proceedings of the Twenty-Second Workshop on Geothermal Reservoir Engineering, pp. 123-130, Stanford University, Stanford, Calif, USA, 1997.

[18] L. A. Derry, M. J. Evans, R. Darling, and C. France-Lanord, "Hydrothermal heat flow near the Main Central Thrust, central 
Nepal Himalaya," Earth and Planetary Science Letters, vol. 286, no. 1-2, pp. 101-109, 2009.

[19] C. Forster and L. Smith, "The influence of groundwater flow on thermal regimes in mountainous terrain: A model study," Journal of Geophysical Research, vol. 94, no. B7, p. 9439, 1989.

[20] J. E. Faulds, V. Bouchot, I. Moeck, and K. Oǧuz, "Structural controls on geothermal systems in western Turkey: A preliminary report," in Proceedings of the Geothermal Resources Council Annual Meeting 2009, Geothermal 2009, pp. 334-340, October 2009.

[21] V. Harcouët-Menou, L. Guillou-Frottier, A. Bonneville, P. M. Adler, and V. Mourzenko, "Hydrothermal convection in and around mineralized fault zones: Insights from two- and threedimensional numerical modeling applied to the Ashanti belt, Ghana," Geofluids, vol. 9, no. 2, pp. 116-137, 2009.

[22] F. Magri, S. Möller, N. Inbar et al., "2D and 3D coexisting modes of thermal convection in fractured hydrothermal systems Implications for transboundary flow in the Lower Yarmouk Gorge," Marine and Petroleum Geology, vol. 78, pp. 750-758, 2016.

[23] T. Gleeson and S. E. Ingebritse, Crustal Permeability, John Wiley \& Sons, Ltd, Chichester, UK, 2012.

[24] S. Bellani, A. Brogi, A. Lazzarotto, D. Liotta, and G. Ranalli, "Heat flow, deep temperatures and extensional structures in the Larderello Geothermal Field (Italy): Constraints on geothermal fluid flow," Journal of Volcanology and Geothermal Research, vol. 132, no. 1, pp. 15-29, 2004.

[25] R. Henley and A. Ellis, "Geothermal systems ancient and modern: a geochemical review," Earth-Science Reviews, vol. 19, no. 1, pp. 1-50, 1983.

[26] W. M. Calvin, E. F. Littlefield, and C. Kratt, "Remote sensing of geothermal-related minerals for resource exploration in Nevada," Geothermics, vol. 53, pp. 517-526, 2015.

[27] V. F. Bense, T. Gleeson, S. E. Loveless, O. Bour, and J. Scibek, "Fault zone hydrogeology," Earth-Science Reviews, vol. 127, no. 2, pp. 171-192, 2013.

[28] C. A. J. Wibberley, G. Yielding, and G. Di Toro, "Recent advances in the understanding of fault zone internal structure: A review," Geological Society Special Publication, vol. 299, pp. 533, 2008.

[29] R. J. Knipe, G. Jones, and Q. J. Fisher, "Faulting, fault sealing and fluid flow in hydrocarbon reservoirs: an introduction," Geological Society Special Publication, vol. 147, pp. vii-xxi, 1998.

[30] H. Fossen and A. Bale, "Deformation bands and their influence on fluid flow," AAPG Bulletin, vol. 91, no. 12, pp. 1685-1700, 2007.

[31] G. Ballas, R. Soliva, J.-P. Sizun, A. Benedicto, T. Cavailhes, and S. Raynaud, "The importance of the degree of cataclasis in shear bands for fluid flow in porous sandstone Provence, France," AAPG Bulletin, vol. 96, no. 11, pp. 2167-2186, 2012.

[32] G. Yielding, B. Freeman, and D. T. Needham, "Quantitative fault seal prediction," Am. Assoc. Pet. Geol. Bull, vol. 81, pp. 897-917, 1997.

[33] N. G. Lindsay, F. C. Murphy, J. J. Walsh, and J. Watterson, "Outcrop studies of shale smears on fault surfaces," Geol. Model. Hydrocarb. Reserv. Outcrop Analog, 1993.

[34] D. R. Faulkner, C. A. L. Jackson, R. J. Lunn et al., "A review of recent developments concerning the structure, mechanics and fluid flow properties of fault zones," Journal of Structural Geology, vol. 32, no. 11, pp. 1557-1575, 2010.

[35] T. M. Mitchell and D. R. Faulkner, "Towards quantifying the matrix permeability of fault damage zones in low porosity rocks," Earth and Planetary Science Letters, vol. 339-340, pp. 2431, 2012.

[36] J. S. Caine, J. P. Evans, and C. B. Forster, "Fault zone architechture and permeability structure," Geology, vol. 24, pp. 1025-1028, 1996.

[37] J. V. Rowland and R. H. Sibson, "Structural controls on hydrothermal flow in a segmented rift system, Taupo Volcanic Zone, New Zealand," Geofluids, vol. 4, no. 4, pp. 259-283, 2004.

[38] J. C. Long and P. A. Witherspoon, "The relationship of the degree of interconnection to permeability in fracture networks," Journal of Geophysical Research, vol. 90, no. B4, pp. 3087-3097, 1985.

[39] J. H. Ligtenberg, "Detection of Fluid migration pathways in seismic data: Implications for fault seal analysis," Basin Research, vol. 17, no. 1, pp. 141-153, 2005.

[40] J. E. Faulds and G. Melosh, "A preliminary structural model for the blue mountain geothermal field, Humboldt County, Nevada," in Proceedings of the Geothermal Resources Council Annual Meeting 2008: "Geothermal - Gaining Steam", pp. 234239, October 2008.

[41] M. Person, A. Hofstra, D. Sweetkind et al., "Analytical and numerical models of hydrothermal fluid flow at fault intersections," Geofluids, vol. 12, no. 4, pp. 312-326, 2012.

[42] R. Soliva and A. Benedicto, "A linkage criterion for segmented normal faults," Journal of Structural Geology, vol. 26, no. 12, pp. 2251-2267, 2004.

[43] J. Walsh, W. Bailey, C. Childs, A. Nicol, and C. Bonson, "Formation of segmented normal faults: a 3-D perspective," Journal of Structural Geology, vol. 25, no. 8, pp. 1251-1262, 2003.

[44] R. H. Sibson, "Fluid involvement in normal faulting," Journal of Geodynamics, vol. 29, no. 3-5, pp. 469-499, 2000.

[45] Q. J. Fisher and R. J. Knipe, “The permeability of faults within siliciclastic petroleum reservoirs of the North Sea and Norwegian Continental Shelf," Marine and Petroleum Geology, vol. 18, no. 10, pp. 1063-1081, 2001.

[46] S. E. Laubach, J. E. Olson, and J. F. W. Gale, "Are open fractures necessarily aligned with maximum horizontal stress?" Earth and Planetary Science Letters, vol. 222, no. 1, pp. 191-195, 2004.

[47] D. Barton, C. A. Zoback, and M. D. Moos, "Fluid flow along potencially active faults in crystalline rock," Geology, vol. 23, pp. 683-686, 1995

[48] S. C. Cox, C. D. Menzies, R. Sutherland, P. H. Denys, C. Chamberlain, and D. A. H. Teagle, "Changes in hot spring temperature and hydrogeology of the Alpine Fault hanging wall, New Zealand, induced by distal South Island earthquakes," Geofluids, vol. 15, pp. 216-239, 2015.

[49] A. Souriau and H. Pauchet, "A new synthesis of Pyrenean seismicity and its tectonic implications," Tectonophysics, vol. 290, no. 3-4, pp. 221-244, 1998.

[50] M. Krimissa, "Application des méthodes isotopiques à létude des eaux thermales en milieu granitique (Pyrénées, France)," 1995.

[51] P. Labaume, F. Meresse, M. Jolivet, A. Teixell, and A. Lahfid, "Tectonothermal history of an exhumed thrust-sheet-top basin: An example from the south Pyrenean thrust belt," Tectonics, vol. 35, no. 5, pp. 1280-1313, 2016.

[52] G. Guitard, B. Laumonier, and A. Autran, "Notice explicative, Carte géologique France (1: 50.000), feuille Prades (1095), Orléans, BRGM,” 1998.

[53] F. Arthaud and S. Pistre, "Les fractures et les paléoncontraintes du granite hercynien de Millas (zone axiale des Pyrénées): 
un cas d'étude la tectonique cassante d'un aquifère de socle," Geodinamica Acta, vol. 6, no. 3, pp. 187-201, 1993.

[54] O. Maurel, L’exhumation de la Zone Axiale des Pyrénées orientales: une approche thermo-chronologique multi-méthodes $d u$ rôle des failles [Ph.D. Thesis], Université Montpellier II-Sciences et Techniques du Languedoc, 2003.

[55] J.-M. Carozza, "Evolution des systèmes géomorphologiques en contexte orogenique: l'exemple des bassins d'alimentation du Roussillon (Pyrénées Orientales)," in Approche Morphotectonique, vol. 2, Toulouse, France, 1998, http://www.theses.fr/ 1998TOU20070.

[56] O. Maurel, M. Brunel, and P. Monié, "Exhumation cénozoïque des massifs du Canigou et de Mont-Louis (Pyrénées orientales, France)," Comptes Rendus-Geoscience, vol. 334, no. 12, pp. 941948, 2002.

[57] B. Delcaillau, J. Carozza, and M. Font, "Le segment nord de la faille de la Tet (Pyrénées-Orientales): fonctionnement néogène et implications géomorphologiques," Bulletin de la Société Géologique de France, vol. 175, no. 3, pp. 257-272, 2004.

[58] X. Goula, C. Olivera, J. Fleta et al., "Present and recent stress regime in the eastern part of the Pyrenees," Tectonophysics, vol. 308, no. 4, pp. 487-502, 1999.

[59] A. Briais, R. Armijo, T. Winter, and P. Tapponier, "Morphological evidence for Quaternary normal faulting and seismic hazard in the Eastern Pyrenees," Annales Tectonicae, vol. 4, pp. 19-42, 1990.

[60] M. Calvet, "Régimes des contraintes et volumes de relief dans l'est des Pyrénées/Stress regimes and volumes of reliefs in the Eastern Pyrenees," Geomorphologie: Relief, Processus, Environnement, vol. 5, no. 3, pp. 253-278, 1999.

[61] C. Petit and F. Mouthereau, "Steep topographic slope preservation by anisotropic diffusion: An example from the Neogene Têt fault scarp, eastern Pyrenees," Geomorphology, vol. 171-172, pp. 173-179, 2012.

[62] J. Carozza and B. Delcaillau, "Drainage basins response to active tectonics: example from Eastern Pyrenees. Morphotectonic approach," Geomorphologie: Relief, Processus, Environnement, vol. 6, no. 1, pp. 45-60, 2000.

[63] O. Maurel, P. Moniè, R. Pik, N. Arnaud, M. Brunel, and M. Jolivet, "The Meso-Cenozoic thermo-tectonic evolution of the Eastern Pyrenees: An 40Ar/39Ar fission track and (U-Th)/He thermochronological study of the Canigou and Mont-Louis massifs," International Journal of Earth Sciences, vol. 97, no. 3, pp. 565-584, 2008.

[64] P. Lacan and M. Ortuño, "Active Tectonics of the Pyrenees: A review/Revisión de la tectónica activa de los Pirineos," Journal of Iberian Geology, vol. 38, no. 1, 2012.

[65] M. Calvet, Y. Gunnell, and M. Delmas, "The têt river valley: a condensed record of long-term landscape evolution in the pyrenees," in Landscapes and Landforms of France, World Geomorphological Landscapes, pp. 127-138, Springer, Dordrecht, Netherlands, 2014.

[66] H. Philip, J. Bousquet, and J. Escuer, "Présence de failles inverses d'âge quaternaire dans l'Est des Pyrénées: implications sismotectoniques," Comptes Rendus Hebdomadaires des Séances de l'académie des Sciences, pp. 1239-1245, 1992.

[67] M. Genti, J. Chery, P. Vernant, and A. Rigo, "Impact of gravity forces and topography denudation on normal faulting in Central-Western Pyrenees: Insights from 2D numerical models," Comptes Rendus - Geoscience, vol. 348, no. 3-4, pp. 173-183, 2016.
[68] P. Vernant, F. Hivert, J. Chéry, P. Steer, R. Cattin, and A. Rigo, "Erosion-induced isostatic rebound triggers extension in low convergent mountain ranges," Geology, vol. 41, no. 4, pp. 467470, 2013.

[69] Y. Caballero, C. Gironde, and E. Le Goff, "Ressource en eau thermale de la station d'Amelie-les-Bains. Etat des lieux," Rapport BRGM/RP-60618-FR, 2012.

[70] B. Ladouche, C. Lamotte, E. Le-Goff, and P. Vigouroux, "Etat des lieux ressource en eau thermale du site des Escaldes (66)," Rapport Final BRGM/RP-63985-FR, 2014.

[71] N. Courtois, P. Le Strat, and P. Vigouroux, "Vigouroux, Valorisation de la ressource en eau chaude et developpement local du Canton d'Olette (66)," BRGM/RP-53078- FR, 2004.

[72] V. Petit, E. Le Goff, and N. Brisset, "Ressource en eau thermale des Thermes de Vernet-Les-Bains - Etat des lieux (Pyrenees Orientales)," BRGM/RP-59182-FR, 2010.

[73] F. Velard and M. Combarnous, "A hot-spring model-heattransfert in the rising branch of the hydrothermal circuit," comptes Rendus Hebdomadaires des Séances de l'académie des Sciences, vol. 291, pp. 63-66, 1980.

[74] H. Serra and B. Sunjuan, "Synthèse bibliographique des géothermomètres chimiques appliqués aux eaux géothermales: rapport final,” BRGM/RP-52430-FR, 2004.

[75] A. Autran, M. Calvet, and M. Delmas, "Carte géologique France (1/50 000), feuille Saillagouse (1094)," Orléans: BRGM, 2004.

[76] R. S. Yeats, K. E. Sieh, C. R. Allen, and E. L. Geist, The Geology of Earthquackes, 1997.

[77] L. Guillou-Frottier, C. Carre, B. Bourgine, V. Bouchot, and A. Genter, "Structure of hydrothermal convection in the Upper Rhine Graben as inferred from corrected temperature data and basin-scale numerical models," Journal of Volcanology and Geothermal Research, vol. 256, pp. 29-49, 2013.

[78] D. L. López and L. Smith, "Fluid flow in fault zones: analysis of the interplay of convective circulation and topographically driven groundwater flow," Water Resources Research, vol. 31, no. 6, pp. 1489-1503, 1995.

[79] K. Eldursi, Y. Branquet, L. Guillou-Frottier, and E. Marcoux, "Numerical investigation of transient hydrothermal processes around intrusions: Heat-transfer and fluid-circulation controlled mineralization patterns," Earth and Planetary Science Letters, vol. 288, no. 1-2, pp. 70-83, 2009.

[80] C. Garibaldi, G.-F. Laurent, J.-M. Lardeaux et al., “Thermal anomalies and geological structures in the Provence basin: Implications for hydrothermal circulations at depth," Bulletin de la Societe Geologique de France, vol. 181, no. 4, pp. 363-376, 2010.

[81] M. L. Gerdes, L. P. Baumgartner, and M. Person, "Convective fluid flow through heterogeneous country rocks during contact metamorphism," Journal of Geophysical Research: Solid Earth, vol. 103, no. 10, pp. 23983-24003, 1998.

[82] M. Rabinowicz, J. Boulègue, and P. Genthon, "Two- and three-dimensional modeling of hydrothermal convection in the sedimented Middle Valley segment, Juan de Fuca Ridge," Journal of Geophysical Research: Solid Earth, vol. 103, no. 10, pp. 24045-24065, 1998.

[83] R. H. Sibson, "Fault rocks and fault mechanisms," Journal of the Geological Society, vol. 133, no. 3, pp. 191-213, 1977.

[84] P. M. Black, "Harmotome from the Tokatoka district, New Zealand," Mineralogical Magazine, vol. 37, no. 288, pp. 453-458, 1969.

[85] W. Brace, "Permeability of crystalline and argillaceous rocks," International Journal of Rock Mechanics and Mining Sciences \& Geomechanics Abstracts, vol. 17, no. 5, pp. 241-251, 1980. 
[86] J. P. Evans, C. B. Forster, and J. V. Goddard, "Permeability of fault-related rocks, and implications for hydraulic structure of fault zones," Journal of Structural Geology, vol. 19, no. 11, pp. 1393-1404, 1997.

[87] M. A. Simms and G. Garven, "Thermal convection in faulted extensional sedimentary basins: Theoretical results from finiteelement modeling," Geofluids, vol. 4, no. 2, pp. 109-130, 2004.

[88] F. Magri, T. Akar, U. Gemici, and A. Pekdeger, "Deep geothermal groundwater flow in the Seferihisar-Balçova area, Turkey: Results from transient numerical simulations of coupled fluid flow and heat transport processes," Geofluids, vol. 10, no. 3, pp. 388-405, 2010.

[89] G. Ballas, H. Fossen, and R. Soliva, "Factors controlling permeability of cataclastic deformation bands and faults in porous sandstone reservoirs," Journal of Structural Geology, vol. 76, pp. 1-21, 2015.

[90] F. M. Chester and J. M. Logan, "Implications for mechanical properties of brittle faults from observations of the Punchbowl fault zone, California," Pure and Applied Geophysics PAGEOPH, vol. 124, no. 1-2, pp. 79-106, 1986.

[91] F. Balsamo, F. Storti, F. Salvini, A. T. Silva, and C. C. Lima, "Structural and petrophysical evolution of extensional fault zones in low-porosity, poorly lithified sandstones of the Barreiras Formation, NE Brazil," Journal of Structural Geology, vol. 32, no. 11, pp. 1806-1826, 2010.

[92] D. R. Faulkner, A. C. Lewis, and E. H. Rutter, "On the internal structure and mechanics of large strike-slip fault zones: Field observations of the Carboneras fault in southeastern Spain," Tectonophysics, vol. 367, no. 3-4, pp. 235-251, 2003.

[93] S. Mahé, Etude de la fracturation et de la déformation d'un massif rocheux aux abords d'une faille d'échelle crustale dans le cadre du tracé du tunnel routier de Saint-Béat [Ph.D. Thesis], Montpellier, France, 2013.

[94] N. R. Backeberg, C. D. Rowe, and N. Barshi, "Alterationweakening leading to localized deformation in a damage aureole adjacent to a dormant shear zone," Journal of Structural Geology, vol. 90, pp. 144-156, 2016.

[95] L. Griffiths, M. J. Heap, F. Wang et al., "Geothermal implications for fracture-filling hydrothermal precipitation," Geothermics, vol. 64, pp. 235-245, 2016.

[96] J. S. Caine, J. P. Evans, and C. B. Forster, "Fault zone architecture and permeability structure," Geology, vol. 2, pp. 1025-1028, 1996.

[97] A. Aydin, "Fractures, faults, and hydrocarbon entrapment, migration and flow," Marine and Petroleum Geology, vol. 17, no. 7, pp. 797-814, 2000.

[98] R. H. Sibson, "Earthquake rupturing as a mineralizing agent in hydrothermal systems," Geology, vol. 15, no. 8, pp. 701-704, 1987.

[99] W. F. Brace, "Permeability of crystalline rocks: New in situ measurements," Journal of Geophysical Research: Solid Earth, vol. 89, no. B6, pp. 4327-4330, 1984. 

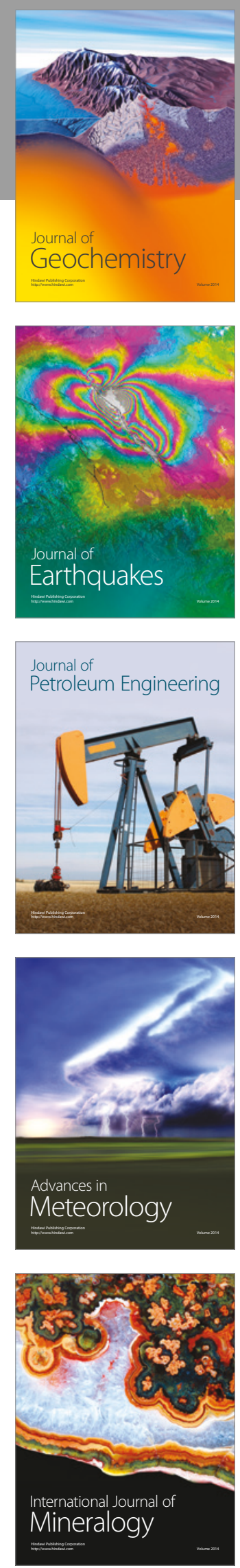
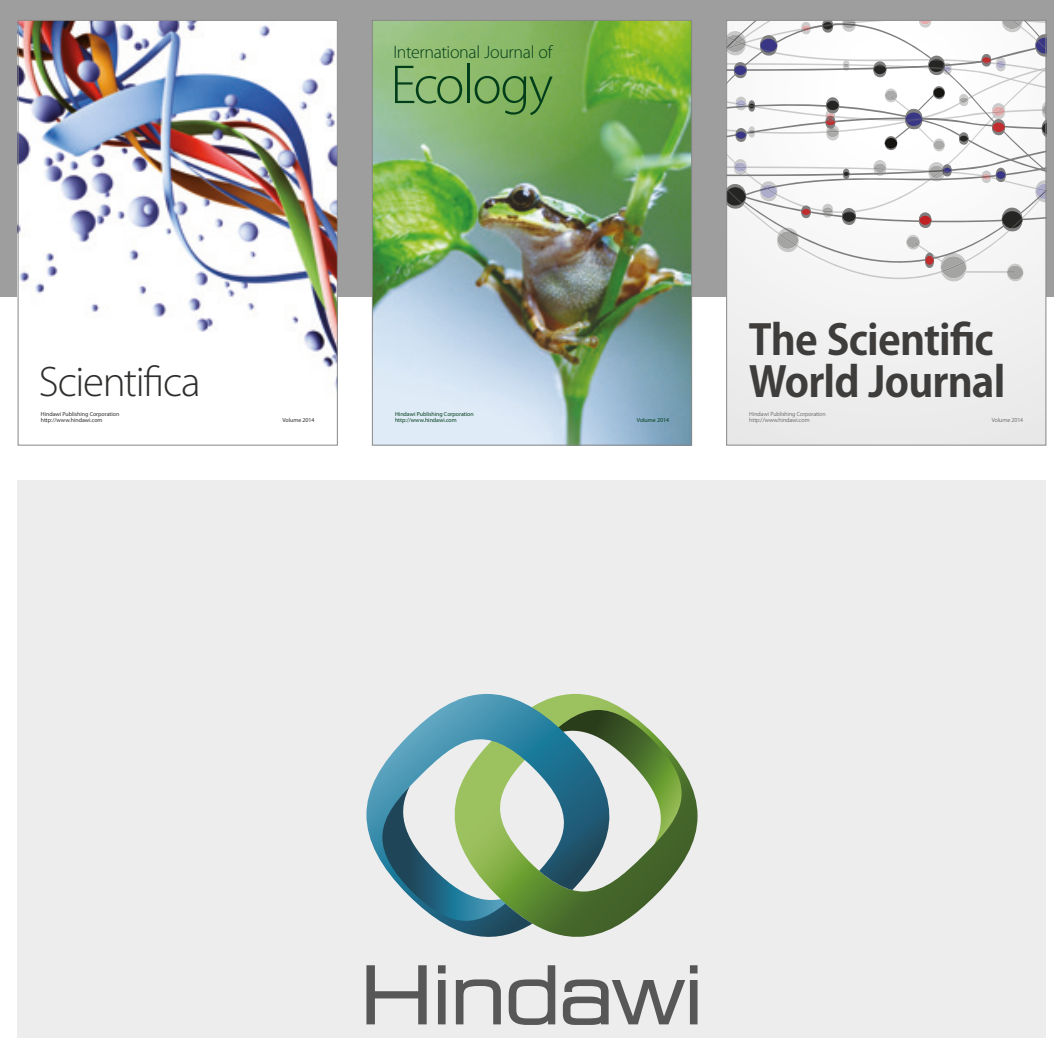

Submit your manuscripts at

https://www.hindawi.com
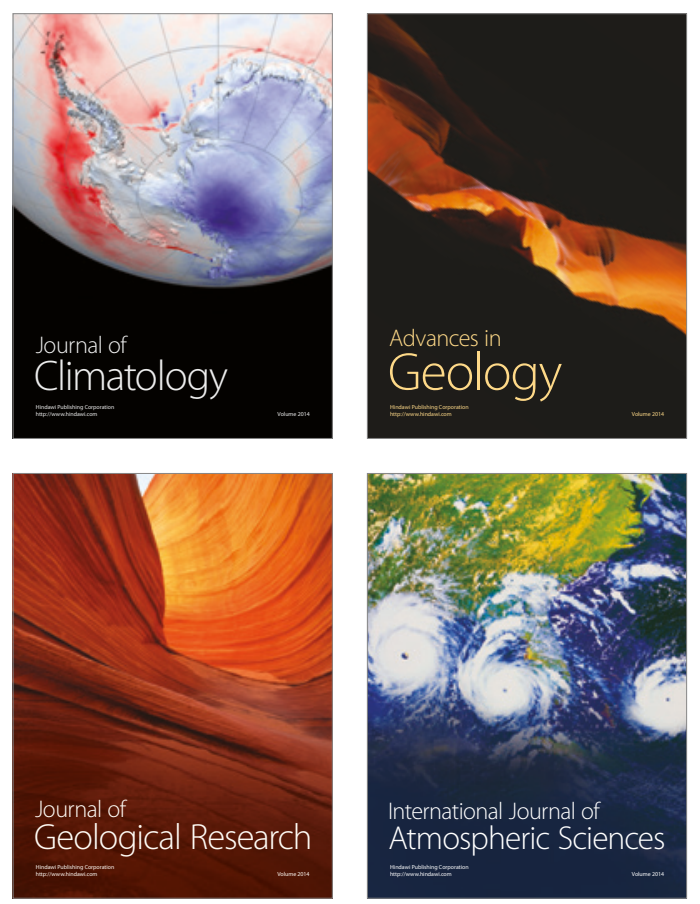

The Scientific

World Journal
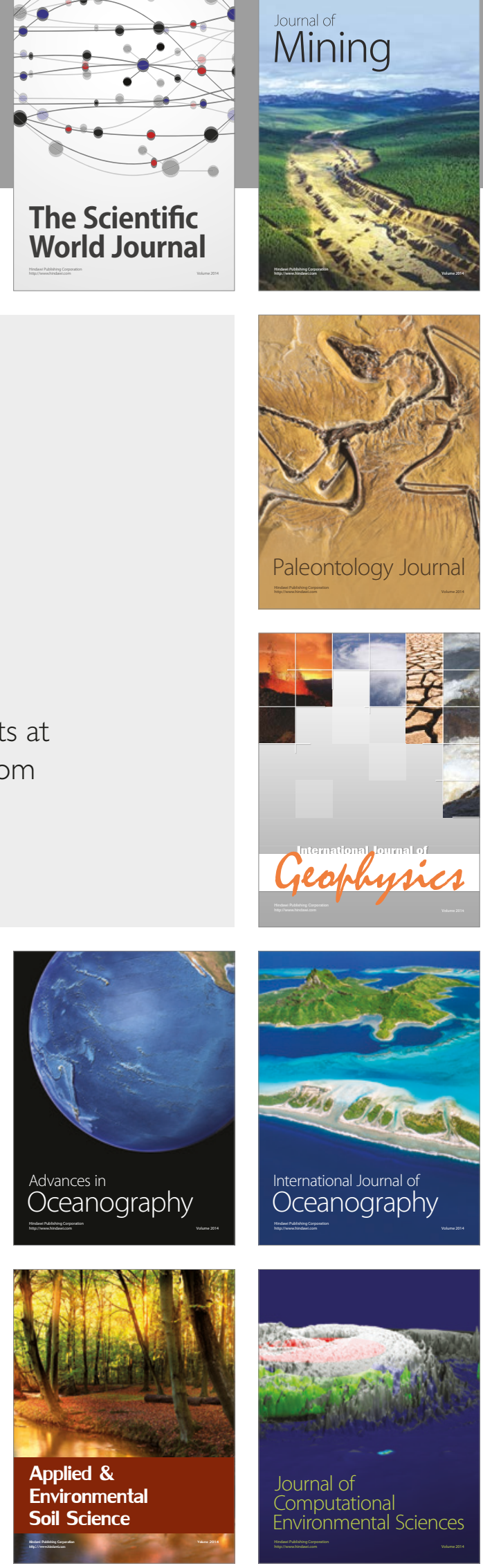